\begin{tabular}{|c|c|c|}
\hline $\begin{array}{l}\text { FATIH } \\
\text { SULTAN } \\
\text { MEHMET } \\
\text { MAKIF UNIVERSITESI } \\
2010\end{array}$ & $\begin{array}{l}\text { FSM İlmî Araştırmalar Insan ve Toplum Bilimleri Dergisi } \\
\text { FSM Scholarly Studies Journal of Humanities and Social Sciences } \\
\text { Sayı/Number } 11 \text { Yıl/Year } 2018 \text { Bahar/Spring } \\
\text { (C2018 Fatih Sultan Mehmet Vakıf Üniversitesi }\end{array}$ & 口iring \\
\hline DOI: & http://dergipark.gov.tr/fsmia & http://dergi.fsm.edu.tr \\
\hline Araştırma Makalesi / Research Article & Geliş Tarihi / Received: 10.03.2018 Kabul Tarihi / Accepted: 17.05.2018 & FSMIAD, 2018; (11): 315-356 \\
\hline
\end{tabular}

Müşkilü'l-Kur'ân

Murat Dinler*

\title{
Öz
}

Bu makalede Müşkilü'l-Kur'ân'1n bir kavram olarak ortaya çıkması ve hicrî III. yüzyıldan X. yüzyıla kadar nasıl bir anlam daralması geçirdiği üzerinde durulmuştur. İlk dönemlerde ayetler arasındaki zâhiri tenâkuz, anlam muğlaklığı, âyetlerdeki mecaz, teşbih, i'râb ve kıraatle alakalı müşkilleri konu alan kavram daha sonraları sadece aralarında çelişki olduğu zannedilen ayetleri konu edinmiştir. Bu kavram daralması birçok tartışmayı da beraberinde getirmiştir. Makalemizde bu tartışmalar analiz edilmiş, bu ilmin doğuşunu hazırlayan başlıca faktörler ve âyetler arasındaki müşkili giderme yolları işlenmiştir. Ayetler arasında var olduğu sanılan ihtilafın sebepleri, hikmetleri ve bu işkâli gidermenin hükmü üzerinde durularak; bu konuda günümüze kadar yapılan çalışmaların kronolojik olarak bibliyografyası verilmiştir.

Anahtar Kelimeler: Müşkil, Müşkilü'l-Kur'ân, teâruz, ihtilaf.

\section{Mushkil al-Qur'an}

\section{Abstract}

In this article, the emergence of Mushkil al-Qur'an as a concept and the process of narrowing in its meaning from the third century to the tenth century of hijra have been elaborated. In the early periods, this concept was associated with the apparent discrepancies between the verses, the ambiguity of meaning, the difficulties in the verses concerning the metaphors, the similitude, the grammer and the reading. But, then, only the verses that seemed to be contradictions between them became the subject of this concept. This narrowing of the concept brought with it many debates. These discussions have been analyzed in our article, and the main factors that have prepared the beginning of this discipline and the ways of eliminating the conflict between the verses have been studied. By focusing on the supposed reasons of the conflict between the verses, the wisdom and the provision of eliminating this conflict, a chronological bibliography of the works done up to this day is given.

Keywords: Difficulty, Mushkil al-Qur'an, conflict, controversy.

Doktora Öğrencisi, Fatih Sultan Mehmet Vakıf Üniversitesi Sosyal Bilimler Enstitüsü Temel İslam Bilimleri Anabilim Dalı, İstanbul/Türkiye, muraddinler@gmail.com, orcid.org/0000-0003-3041-3132 


\section{Giriş}

Kur'ân-1 Kerim, insanları hidâyete erdirmek için ${ }^{1}$ nazım ve mana olarak A1lah Teâla tarafından indirilmiştir. Kur'ân-1 Hakîm, tilâvetiyle ibadet edilen² ve hükümleriyle amel edilmesi gereken ${ }^{3}$ bir kitap olduğu gibi aynı zamanda tefekkür edilmesi istenen bir kitaptır. ${ }^{4}$ Buna binâen âlimler, nüzûl döneminden itibaren bu yüce Kitab’a büyük bir ihtimam göstermişler; üzerinde ilmî çalışmalar yapmışlar; âyetlerini tefsir etmişler, ondaki ilimleri istihraç etmişler; bu konuda gayretlerini esirgememişlerdir. Her asırda artarak devam edegelen bu çalışmalar neticesinde her nesil kendisinden sonrakilere büyük bir ilim mirası devretmiştir. Öyle ki, Kur’ân ilimlerinin bütün nev‘ilerini içine alan eserler telif edildiği gibi, her nev`i için de müstakil eserler yazılmaya ihtiyaç duyulmuştur. Şüphesiz Kur’ân ilimleri sahasında yapılan bu nev'i çalışmaların en önemlilerinden birisi de Müşkilü'l-Kur'ân ilmidir. Kur'ân-1 Kerim âyetleri arasında zihne takılan sorulara çözümler üretmesi ve muhataplara ikna edici cevaplar vermek gibi görevleri üstlenmesi açısından bu ilim önemli bir yere sahiptir. Bu nedenle günümüze kadar üzerinde birçok çalışmalar yapılmıştır. ${ }^{5}$

Diğer çalışmalardan farklı olarak bu makalede, “müşkilü’l-Kur’ân” kavramı etrafındaki tartışma incelenecek; Süyûti’nin (v. 911/1505) çizdiği yeni çerçeve sonrasında yani sadece zahirde çelişkili gibi görünen âyetler kapsamında bu konu toplu olarak ele alınacaktır. Çalışmamıza bir zemin teşkil etmesi bakımından önce müşkil ve Kur’ân kelimelerinin sözlük (lügat) ve terim (1stılah) anlamlarını açıklayıp daha sonra müstakil bir disiplin olarak Müşkilü’l-Kur'ân'ın kavramsal tanımını vermek yerinde olacaktır.

\section{Müşkil'in Lügat Anlamı}

“Müşkilü’l-Kur'ân” sözü, muzaf olan "müşkil” lafzıyla, muzafun ileyh olan “Kur’ân” kelimesinden oluşturulmuş bir izafet terkibidir. Müşkil kelimesi إثْكالْ " masdarından türemiş olup ismi faildir. "Benzerleri ve emsalinin arasına karışan şey” demektir.6 Arapların أَثْكَلَ النََُّّْْ sözü bu manadadır. Zira Araplar, bir şey di-

1 Bakara 2/185.

2 Muhammed Abdülazîm ez-Zürkânî (v. 1367/1948), Menâhilü'l- 'irfân fî̀ 'ulûmi'l-Kur'ân, 2. bs., nşr. Ahmed Şemsüddîn, Beyrut, Dârü'l-kütübi'l-'ilmiyye, 1424/2004, s. 17.

3 Mâide 5/48; Câsiye 45/18.

4 Muhammed 47/24.

5 II. (VIII.) yüzyılın başlarından günümüze kadar yapılan bu çalışmaların bir listesini makalenin sonunda vereceğiz.

6 el-Cürcânî, Ebü'l-Hasen Muhammed b. Alî (v. 816/1413), et-Ta 'rîfât, Misır, el-Matbaatü'l-hayriyye, 1306 h., s. 94; Muhammed b. Ali et-Tehânevî, Keşşâfü ıstılâhâti'l-fünûn ve'l'ulûm, Kalküta 1862, (İstanbul, Kahraman yayınları ofset, 1404/1984), I/786. 
ğerine benzeyip ayırt edilmediği zaman o şey için أَنْكَلَ الثنَّيْيُ derler.7 İbn Fâris (v. 395/1004) demiştir ki: ش ك كل harflerinden türeyen kelimelerin büyük çoğunluğu,

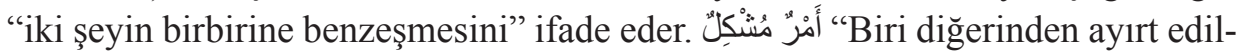
meyen iş" sözü de bu manadan alınmıştır. ${ }^{8}$

\section{Müşkil'in Istılah Anlamı}

Müşkil terimi, fikıh usûlü, hadis ve ulûmü'l-Kur'ân ilim dallarında müşterek olarak kullanılmaktadır. Bununla birlikte bu terim, bahsedilen ilimlerde farklı şekillerde tarif edilmiştir. Şimdi bu tarifleri inceleyelim.

F1kıh usûlü âlimleri müşkilin birçok tarifini yapmışlardır. Abdülvehhâb Hallâf’a (1888-1956) göre usûlcülerin 1stılahında müşkilin tarifi şöyledir: "Kendisinden kastedilen mana anlaşılmayan ve bu manayı açıklayan hariçten bir karineye ihtiyaç duyan lafizdır." Hallâf, müşkildeki kapalılık sebebinin ya lafzın kendisinden ya da nastan anlaşılan mananın diğer bir nastan anlaşılan manayla çelişmesinden kaynaklandığını söyler. ${ }^{9}$

Hadis âlimleri ise, müşkile birden çok tarif yapmışlardır. ${ }^{10}$ Tahâvî'nin (v. 321/933) meşhur eseri Şerhu müşkili'l-âsâr'1 tahkik eden Şuayb Arnaût (1928/2016) bu eserin mukaddimesinde Tahâvî'nin metoduna dair bilgi verdikten sonra müşkilü'l-hadisi şöyle tanımlar: “Müşkilü’l-hadis, Resulullah'tan gelen sahih bir hadisin bazen zahiren ya da hakikaten başka bir hadisle çelişmesi, bazen de Kur'ân-1 Kerim'e, Arap diline, akla veya hisse (duyularla algılanana) muhalif görünmesidir." 11

Tefsir ve ulûmü'l-Kur'ân âlimlerine göre ise, "müşkil" kavramı ilk dönemden günümüze kadar tarihi bir süreçten geçmiştir. Şöyle ki, ilk dönem tefsir âlimlerinden İbn Kuteybe'ye (v. 276/889) göre müşkil “diğeriyle benzeşmesinden veya başka bir sebepten dolayı anlamında kapalılık olan âyete" denir." ${ }^{2}$ İbn Akîle de (v. 1150/1737) buna benzer bir tarif yaparak Müşkilü'l-Kur'ân'1 şöyle

7 el-Cürcânî, et-Ta 'rîfât, s. 94; el-Fîrûzâbâdî, Ebü’t-Tâhir Mecdüddîn Muhammed b. Ya'kûb (v. 817/1415), el-Kâmûsü'l-muhît, Beyrut, Müessesetü'r-risâle, 1416/1996, s. 1411.

8 İbn Fâris, Ebü'l-Hüseyn Ahmed b. Fâris (v. 395/1004), Mu 'cemü mekâyîsi'l-luga, nşr, Abdüsselâm Muhammed Harun, 6 c., Kâhire, 1366-1371/1946-1951, 1389-1392/1969-1972, (Bask1 yeri yok, Darü'l-fikr ofset, 1399/1979) C: III, s. 204.

9 Abdülvehhâb Hallâf, İlmü usûli'l-fikh, Kâhire, Dârü'l-hadîs, 1423/2003, s. 198.

$10 \mathrm{Bu}$ tariflerden dokuz tanesi için bkz. http://www.alssunnah.org/ar/site-sections/moshkil-alhadith/252-2007-05-01-00-55-05

11 et-Tahâvî, Ebû Ca ‘fer Ahmed b. Muhammed, Şerhu müşkili'l-âsâr, nşr. Şuayb el-Arnaût, 16 c., Beyrut, Müessesetü'r-risâle, 1415/1994, C: I (mukaddime), s. 7.

12 İbn Kuteybe, Ebû Muhammed Abdullah b. Müslim ed-Dîneverî, Te 'vîlü müşkili'l-Kur'ân, nşr. Sa‘d b. Necdet Ömer, Beyrut, Müessesetü'r-risâle nâşirûn, 1435/2014, s. 120. 
tarif etmiştir: "Manası muhataba karışık gelen ve ancak başka bir delil yardımıyla anlaşılan âyettir." ${ }^{13}$ Burada açıkça görüldüğü gibi, müşkil terimi geniş bir anlamda kullanılmış olup âyetlerde ortaya çıkabilecek olan bütün işkâl yönlerini içine almaktadır. Bu işkâlleri ana hatlarıyla şöyle özetleyebiliriz:

Kelimedeki anlamın kapalı olmasıyla ilgili müşkil,

Âyetin tefsirindeki farklı anlayışla alakalı müşkil,

Âyetler arasında çelişki olduğu sanılmasından kaynaklanan müşkil,

I'râbla ilgili müşkil,

Kıraatlerle alakalı müşkil. ${ }^{14}$

Nitekim tefsirlerde ve müşkilü'l-Kur'ân'a dair yazılan müstakil eserlerde bu konuların herbirine dair örnekleri görmekteyiz. İbn Kuteybe'nin Te'vîlü müsskili'l-Kur'ân'1, Taberî'nin (v. 310/923) Câmiu'l-beyân'’, Ebû Hayyân'ın (v. 745/1344) el-Bahrü'l-muhît'i ve İzzeddîn b. Abdisselâm'in (v. 660/1262) Fevâid fì müşkili'l-Kur'ân'1 işkâlin bütün bu yönlerine yer veren eserlerden bazılarıdır.

F1kıh usûlü, hadis ve tefsir âlimlerine göre yukarıda bahsettiğimiz müşkilin tarifinden yola çıkarak özetle şunu söylememiz mümkündür: Bu üç ilme göre müşkil, başka bir nasla ihtilaf eden nasları konu edindiği gibi, mânası zor anlaş1lan nasları da konu edinir.

Süyûtî (v. 911/1505) ise "müşkil" kavramını bahsi geçen tariflerden daha hususi bir şekilde tanımlamıştır. Ona göre, “Müşkilü'l-Kur’ân, âyetler arasında ilk bakışta tenâkuz izlenimi veren durumdur." ${ }^{15} \mathrm{Bu}$ iki tarif arasındaki mukayeseyi birazdan gelecek olan “Tarihi Süreçte Müşkilü'l-Kur'ân Kavramı Etrafinda Oluşan Tartışma” başlığında inceleyeceğiz.

13 İbn Akîle, Cemâlüddîn Ebû Abdillah Muhammed b. Ahmed el-Mekkî (v. 1150/1737), ez-Ziyâde ve'l-ihsân fî 'ulûmi'l-Kur'ân, nşr. Muhammed Safâ Hakkî (nev'1-45), Fehd b. Ali el-Ândes (nev‘46-90), İbrâhîm b. Muhammed el-Mahmûd (nev`91-119), Muslih b. Abdülkerîm es-Sâmidî (nev`120-143), Hâlid Abdülkerîm el-Lâhim (nev`144-154), 10 c., el-'İmârâtü'l-Arabiyyetü'l-müttahide， Merkezü'l-buhûs ve'd-dirâsât-Câmi'atü'ş-şârika, 1427/2006, C: V, s. 134.

14 Bu kısımlar ve âyet-i kerimelerden örnekleri için bkz. Abdullah b. Hamed el-Mansûr, Müşkilü'l-Kur'âni'l-Kerîm, 2. bs., el-Memleketü'l-Arabiyyetü's-Su'ûdiyye, Dâr'ü-bni'l-Cevzî, 1433 h., s. 42-49.

15 es-Süyûtî Ebü'l-Fazl Celâlüddîn Abdurrahmân b. Ebî Bekr, el-İtkân fî 'ulûmi'l-Kur'ân, nşr. Mustafa Dîb el-Bugâ, 2 c., Beyrut, Dâr'ü-bni Kesîr, 1416/1996, C: II, s. 724. 


\section{Kur'ân'ın Lügat Anlamı}

Kur’ân kelimesi sözlükte masdardır. Ve okumak manasındaki kıraat (قِّرَ) ile eş anlamlıdır (müteradif). Nitekim şu âyet, Kur’ân kelimesinin “okumak” anla-

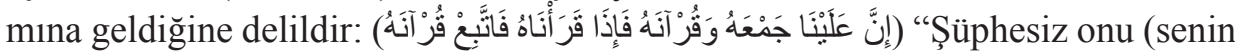
hâfizanda) toplamak da, senin onu okuman da ancak bize aittir. Öyleyse (Cebrail vasıtasıyla) biz onu (sana) okuduğumuz zaman, sen onun okunuşunu takip et"16.

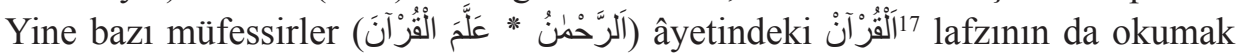
manasına geldiğini söylemişleridir. ${ }^{18}$ Buna göre âyet, "(İnsana) okumayı Rahmân öğretti” anlamındadır.

\section{Kur'ân'ın Istılah Anlamı}

Kur'ân kelimesi, usûl ve fikıh âlimleri ile dilcilerin 1stılahında: "Resulullah aleyhisselam'a indirilen, mushaflarda yazılan, mütevatir olarak nakledilen ve okunuşuyla ibadet edilen muciz kelamdır"19 şeklinde tarif edilmektedir. Menna el-Kattân tarifte geçen "okunmasıyla ibadet edilen” sözünü, "okunması ibadet olarak emredilen" diye açıklamaktadır. ${ }^{20}$

\section{Tarihi Süreçte “Müşkilü’l-Kur’ân” Kavramı Etrafında Oluşan Tartışma}

“Müşkilü'l-Kur'ân” kavramı hicrî III. yüzyıldan X. yüzyıla kadar geniş bir anlamda kullanılmaktaydı. X. yüzyıldan sonra bu kavramın anlamında bir daralma göze çarpmaktadır. Tesbitimize göre müşkilü’l-Kur'ân tabirini daralmış anlamıyla yani “Kur'an âyetleri arasında ilk bakışta var olduğu sanılan ihtilaf” anlamında ilk defa kullanan Süyûtî' dir. O, tefsir ilmine dair ilk yazdığı et-Tahbîr $f i$ 'ilmi t-tefsîr isimli eserin kırk altıncı nev 'isini "Müşkil”' başlıklı konuya tahsis etmiştir. Süyûtî konunun başında, bu isimde bir nev'iyi kendisinin ilave ettiğini zikreder. Ona göre tefsir ilmi ve Kur'ân ilimlerine dair yazılan kitaplar içerisinde böyle bir başlık yoktur. Daha sonra şunları kaydeder:

"Hadis alanında "Muhtelifü'l-hadîs” nev'isi ne ise, "Müşkilü'l-Kur'ân” nev 'isi de öyledir. Muhtelifü'l-hadîs ilmi ilk baklşta çelişkili gibi görünen hadisleri incelediği gibi, Müşkilü'l-Kur'ân ilmi de aralarında tenâkuz olduğu sanılan âyetleri inceler. Müteşâbih ile müşkil arasındaki fark ise şudur: Müteşâbih, kendi-

16 Kiyâmet 75/17-18; ez-Zürkânî, Menâhilü'l-'irfân fí 'ulumi'l-Kur'ân, s. 17.

17 Rahmân 55/1-2.

18 Subhî es-Sâlih (1926-1986), Mebâhis fì 'ulûmi'l-Kur'ân, 27. bs., Beyrut, Dârü'l-'ilm li'lmelâyîn, 2007, s. 19.

19 Zürkânî, Menâhilü'l- 'irfân, s. 17.

20 Menna' Halîl el-Kattân (1925-1999), Mebâhis fì 'ulûmi'l-Kur'ân, 35 bs., Beyrut, Müessesetü'r-risâle, 1998/1418, s. 20. 
sinden kastedilen mana anlaşılmayan âyetlerdir. Müsskil ise, kendisinden kastedilen mana uzlaştırma (cem) yoluyla anlaşılan âyetlerdir. Çünkü Müşkilü'l-Kur'ân,

"Kelâmullah'ın münezzeh olduğu çelişki görünümündeki âyetler" demektir... Arap dilindeki kelimelerin iştikaklarını bilen, bunları kullanmakta mâhir olan, lügatın inceliklerine vâklf olan basiret sahibi kimselere müşkil âyetlerin arasını birleştirip uzlaştırmak gizli değildir." ${ }^{21}$

Süyûtî, et-Tahbîr'den sonra aynı sahada daha geniş olarak telif ettiği el-İtkân fî̀ 'ulûmi'l-Kur'ân isimli eserinin kırk sekizinci nev'isinde bu konuyu "Müşkilü'l-Kur'ân ve mûhimü'l-ihtilâf ve't-tenâkuz" başlığı altında incelemiş ve müşkilü'l-Kur'ân kavramını: “Kur'ân-1 Kerim âyetleri arasında tezat gibi görünen durumlardır" diye tarif etmiştir. ${ }^{22}$

Görüldüğü gibi Süyûtî, et-Tahbîr' deki tarifinde bu vasfa sahip âyetleri müşkil diye isimlendirirken, el-Ittkân'da ise, âyetlerde ihtilaf gibi görünen durumu müşkil diye isimlendirmiştir. Her hâlukârda Süyûtî, "müşkil" kavramına öncekilerden daha hususî bir anlam çizmiştir. Zira önceki dönemde müşkilü'l-Kur'ân'a dair telif edilen eserler bu kavramı, kıraat ihtilafi, Kur'ân'da lahin ${ }^{23}$ iddiası, zâhiri ihtilaf, müteşabih, mecaz, istiare, hazf, tekrar, ziyâde, kinâye, ta rîz, müşterek lafız (sesteş) ve benzeri konuları kapsayacak şekilde ele almaktadırlar. İbn Kuteybe'nin Te 'vîlü müşkili 'l-Kur'ân'1 ve Nîsâbûrî'nin (v. 553/1158'den sonra) Bâhirü'l-burhân fî me 'ânî müşkilâti'l-Kur'ân'1 bunun örneklerindendir. Süyûtî ise, müşkilü'l-Kur'ân kavramını, bahsedilen bu konular içinden sadece birine tahsis etmiş yani "aralarında ilk bakışta tenâkuz olduğu sanılan âyetler" anlamında kullanmıştır.

Onun bu kavrama getirdiği tanım kendisinden sonrakileri de etkilemiştir. Muhammed Emîn el-Hatîb, Tîcânü'l-beyân fì müşkilâti'l-Kur'ân isimli eserini büyük ölçüde aralarında ihtilaf görüntüsü olan âyetlere ayırmıştır. Yine İsmail Cerrahoğlu'nun Tefsir Usûlü, Muhsin Demirci'nin Tefsir Usûlü ve Tarihi isimli eserlerindeki müşkilü'l-Kur'ân bölümleri ve Sabri Demirci'nin Kur'an'da Müşkül Âyetler adlı basılmış doktora tezi de müşkilü'l-Kur'ân konusunu Süyûtî'nin zikrettiği tarif çerçevesinde ele alan çalışmalardan bazılarıdır. ${ }^{24}$

21 es-Süyûtî, et-Tahbîr fî 'ilmi't-tefsîr, Beyrut, Dârü'l-kütübi'l-'ilmiyye, 1408/1988, s. 102.

22 es-Süyûtî, el-ítkân, C: II, s. 724.

23 Lahn: Kelimenin harflerinde veya i'râbındaki hatadır. er-Râgıb el-İsfahânî, Ebü’l-Kâsım Hüseyn b. Muhammed (v. V./XI. yüzyılın ilk çeyreği), el-Müfredât fì garîbi'l-Kur'ân, nşr. Safvân Adnân Dâvûdî, 4. bs., Dımaşk, Dârü'l-kalem, 1430/ 2009, s. 738.

24 Başlı̆̆ında "müşkil” veya "işkâl” kelimesi bulunup, hususî olarak "zâhirî ihtilaf” konusunu ele alan çalışmaların bir listesi makalenin sonunda verilmiştir. 
Bununla birlikte İbn Akîle, tenâkuz izlenimi veren âyetlere "müşkil" ismi vermesinden dolayı Süyûtî’ye eleştiri yöneltmiştir. İbn Akîle’ye göre müşkil, manası kapalı olup ancak başka bir delille anlaşılan şeydir. ${ }^{25}$ Ona göre teâruz görünümündeki âyetler, Süyûtî’nin dediği gibi müşkil nev'isinden değildir. Bilakis bu âyetler, aralarında ihtilaf olmadığ 1 halde çelişki vehmi uyandıran âyetleri teşkil etmektedir (Mâ evheme't-tenâkuz ve't-te'âruz ve leyse bi-mütenâkız ve lâ bi-müte'ârız). ${ }^{26}$

İbn Akîle'nin Süyûtî’ye yaptığı itiraza şöyle cevap vermemiz mümkündür: Kanaatimizce Süyûtî, bu tarifi lügavî mecâz (dile dayalı mecaz) yoluyla zikretmiştir. Buradaki mecaz alakası ise, 'âm (genel) olan ismin zikredilip hâs (özel) olan mananın irade edilmesiyle olmuştur. Yani müşkilü'l-Kur'ân tabiri, bütün işkâl konularına şâmil olmakla birlikte Süyûtî’nin tarifinde mecâzi kullanım yoluyla, sadece "tenâkuz ve ihtilaf bâbına" isim verilmiştir. Daha sonra tefsir ilminde müşkilü'l-Kur'ân tabirinin bu anlamda kullanımının yaygınlaşması neticesinde Süyûtî'nin zikrettiği bu tarif, örfte hakîkat (hakîkat-i örfiyye) olmuştur. Yani tefsir ilmi dalında hakîkat olarak kullanılagelmiştir.

Şu da var ki, İbn Akîle'nin yaptığı itirazdan ve bahsetmiş olduğu "müşkil" ve "ihtilaflı gibi görünen âyetler" tanımından bu iki nev'i arasında herhangi bir münasebet yokmuş gibi anlaşılmaktadır. Halbuki bu iki kavram arasında umum-husus münasebeti vardır. Zira her müteârız müşkildir. Fakat her müsskil müteârız değildir. Nitekim İbn Kuteybe'nin Te'vîlü müşkili'l-Kur'ân başlıklı eserinde "aralarında ihtilaf olduğu sanılan âyetler" konusuna yer vermesi de bu iki nev'i arasındaki umum-husus münasebetini göstermesi açısından kayda değerdir.

Ayrıca 'âm lafzın hâs olan anlamda kullanımı Arap dilinde yaygındır. Buna

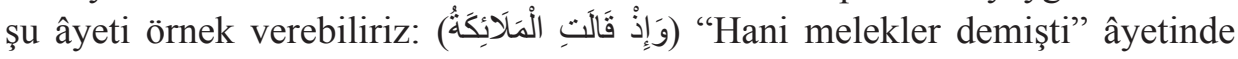
melekler kelimesi zikredilmekle birlikte meleklerden Cebrâil (as) kastedilmiş-

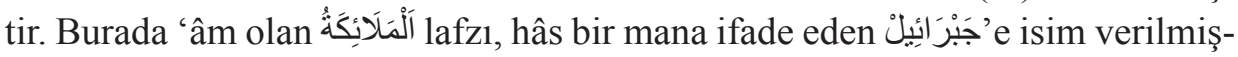
tir ki buna mürsel mecâz denir. ${ }^{27}$ Süyûtî’nin müteârız gibi görünen âyetleri, "Müşkilü'l-Kur'ân" diye isimlendirilmesi de aynı şekilde mürsel mecâz yoluyla olmuştur. Bu kullanımın tefsir ilminde yaygınlaşmasından dolayı da örfte hakîkat olmuştur.

25 İbn Akîle, ez-Ziyâde ve'l-ihsân, C: V, s. 134.

26 İbn Akîle, a.g.e., C: V, s. 196.

27 Muhammed Ali es-Sâbûnî, Safvetü 't-tefâsîr, 4. bs., 3 c., Beyrut, Dârü'l-Kur'âni'l-Kerîm, 1402/1981, C: I, s. 203. 
Bunu ifade etme açısından şöyle bir yaklaştırma yapabiliriz: İbn Kuteybe'ye göre "müteşabih" ile "müşkil" terimleri eşanlamlıdır (müterâdif). ${ }^{28}$ Onun Te'vîlü müşkili'l-Kur' ân adlı eserinde hazıf, ziyâde, tekrar ve diğer konuların tamamına müşkil dendiği gibi, müteşabih de denmektedir. Süyûtî İbn Kuteybe'nin eserinde geçen birçok konudan biri olan yani "zâhirde ihtilaflı görünen âyetler" konusunu, kitabın umumî konularına ait başlık olan "Müşsilü'l-Kur'ân” ile isimlendirdiği gibi, İbn Kuteybe'nin aynı kitabında hususî birer nev'i olarak işlenen hazf, ziyâde ve tekrarlara dair diğer birtakım konuları da Hatîb el-İskâfî (v. 420/1029) Dürretü 't-tenzîl ve İbnü'z-Zübeyr es-Sekafî (v. 708/1308) Milâkü 't-tevîl adlı eserinde "Müteşâbih" başlığı altında ele almışlardır. Hâlbuki İbn Kuteybe bu konuların geneline "müteşâbih" ismini vermekteydi. Görüldüğü gibi "müteşabih" kavramı, İbn Kuteybe'nin adı geçen eserinde bütün konuların genel adı olmakla birlikte, el-İskâfî ve es-Sekafî, bu gibi hususi konuları eserlerinde "müteşabih" başlı̆g 1 altında ele almışlardır. Dolasıyla burada da "müteşabih" kavramı, aynı "müşkil" kavramı gibi mecaz yoluyla bir takım hususî konulara isim verilmiştir.

Ayrıca şunu da belirtmek gerekir ki, mütekaddimîn döneminde umumi manada kullanılan kavramların müteahhirîn döneminde anlam daralmasına uğrayıp hususî anlamda kullanıldıkları görülmektedir. Mesela "mensuh" kavramı böyledir. Şah Veliyullah (v. 1176/1762), mütekaddim âlimler ile müteahhir âlimlerin "nesih" kavramına yaklaşımlarının farklı olduğunu söyler. Ona göre sahâbe ve tâbiîn, neshi lügavî manada yani "bir şeyi diğeriyle izâle etmek" anlamında kullanıyorlar; günümüzdeki usûlcülerin anladığı manada kullanmıyorlardı. Mesela sahâbe ve tâbiîne göre, tahsis, kaydın ittifâkî olduğunu beyan etmek (yani ihtirâzî kayıt değil), kelâmı zahirinden çevirmek gibi konular "nesih" kavramı içine giriyordu. Buna göre ilk dönemde nesih konusunun alanı genişti. Mensuh âyetlerin sayısı bir hayli çoktu. Müteahhir usûlcülere göre ise, mensuh âyetler birbirinden farklılık arz etse de bunlar sınırlı sayıdadır. ${ }^{29}$ "Müşkilü'l-Kur'ân" kavramı da zaman içerisinde değişime uğraması ve anlamının daralması açısından "mensuh âyetler" kavramı gibidir.

Sonuç olarak tefsir ilmi açısından "Müşkilü'l-Kur'ân" 1stılahı, herhangi bir sebeple manası kapalı olan âyetleri içine almakla birlikte daha çok "ihtilaf ve teâruz izlenimi veren âyetler" anlamında kullanılmaktadır. Biz de "Müşkilü’l-Kur'ân" konusunu Süyûtî'nin tarifini esas alarak "aralarında ihtilaf olduğu zannedilen âyetler” çerçevesinde incelemeye çalışacağız.

28 İbn Kuteybe, Te'vîlü müşkili'l-Kur'ân, s. 119-120.

29 Şah Veliyyullah Ahmed b. Abdirrahîm ed-Dihlevî, el-Fevzü'l-kebîr fì usûli 't-tefsîr (trc. Selmân el-Hüseynî en-Nedvî), Dımaşk, Dâru'l-gavsânîli'd-dirâsâti'l-Kur'âniyye, 1429/2008, s. 57-58. 


\section{Müşkilü'l-Kur'ân İlmini Hazırlayan Faktörler ve Bu İlmin Doğuşu}

Kur'ân âyetleri arasında ihtilaf ve tenâkuz zannı risâlet asrında başlamıştır. Zira bazı yahudi ve müşrikler, nâsih ile mensuh âyetler arasında görünen teâruzdan dolayı eleştiri oklarını Kur'ân-1 Kerîm'e yönelterek ona iftirada bulunmuşlardır. Cenâb-1 Hakk birçok âyetinde onların bu iftira ve şüphelerine cevap vermiştir. ${ }^{30}$ Nübüvvet asrındaki ihtilaf vehminin nedeni Arap dilini bilmemekten kaynaklanmıyordu. Bu vehim kâfirler tarafindan Kur'ân ve İslâmı zaafa uğratmak maksadıyla nâsih ile mensuh âyetler etrafında oluşturulmaya çalışılan şüphe ve iftiralar neticesinde ortaya çıkmıştır.

Nübüvvet döneminden sonra insanlar peyderpey İslâm dinine girmeye devam etmişlerdir. Arap olmayan farklı kültür ve dile sahip kimseler, Araplarla kurdukları sosyal iletişimin bir neticesi olarak Arap dilini öğrenmeye ihtiyaç duymuşlardır. İslâm'a giren farklı milletlerin Araplarla karışmaları, Arap dili üzerinde birtakım olumsuz etkilere de neden olmuştur. Bütün bu durumlar ise, Kur'ân dili olan fasih Arapça'yı sâfiyetinden uzaklaştırma tehlikesiyle karşı karşıya getirmiştir. Buna ilaveten Kur'ân-1 Kerim'in nüzûl dönemi üzerinden zaman geçmesi ve insanların Arap diline dair incelik ve hükümleri kavramakta birtakım zorluklar yaşaması da dilde bazı anlaşılmazlıkları beraberinde getirmiştir. Dolayısıyla Kur'ân-1 Kerim'de izaha ihtiyaç duyan bazı âyet ve kelimeler çoğalmış; müşkil âyetler dairesinde genişleme olmuştur.

Ayrıca İbn Kuteybe'nin dediği gibi mülhidler Allah'ın Kitabı'nı hedef alıp onu tenkite kalkıştılar. Fitne çıkarmak ve onu kendi arzularına göre yorumlamak için zayıf anlayışları, hasta bakışlarıyla ondaki müteşâbih ve müşkil âyetlerin peşine düştüler. Kelimeleri asıl anlamlarından çevirdiler. Sonra da onda tenâkuz, ihtilaf, lahn ve nazım bozukluğu var diye hüküm verdiler. $\mathrm{Bu}$ hususta birtakım iddialar ileri sürdüler. Kimi zaman da kalbi zayıf veya yeni Müslüman olan kimseleri kendilerine meylettirip onların kalplerine şüpheler soktular ve itikatlarını zedelediler. ${ }^{31}$

Sonuç olarak bu ilminin doğuşunu hazırlayan etkenleri özetle iki ana grupta toplayabiliriz: Birincisi, bir takım kimselerin Kur'ân hakkında yeterli bilgiye ve kavrayışa sahip olamamaları neticesinde Kur'ân'ı anlayamamaları, diğeri ise İslâm düşmanlarının Müslümanların zihinlerini karıştırmak ve kalplerine şüphe sokmak amaciyla Kur'ân'da tezat bulma faaliyetleridir.

Müşkilü'l-Kur'ân ilminin doğuşuna dair ilk örneklere sahabe döneminde rastlyyoruz. Süyûtî buna örnek olarak, İbn Abbas (ra) (v. 68/687-88) ile ona bir-

30 Bakara 2/106; En'âm 6/33; Nahl 16/101; Fussilet 41/42.

31 İbn Kuteybe, Te 'vîlü müşkili'l-Kur'ân, s. 51. 
takım sorular soran kimse arasında geçen bir hadiseyi zikretmiştir. Saîd b. Cübeyr'den (v. 94/713 [?]) gelen rivâyet şöyledir: Bir adam ${ }^{32}$ İbn Abbas'a gelerek: "Kur'an'da bazı ayetler bana ihtilaflı geliyor" dedi. İbn Abbas (ra): "Nedir onlar?” Kur'an'da şüphe mi var? diye sorunca adam dedi ki: Hayır şüphe yok fakat birbiriyle çelişkili gibi görünen âyetler görüyorum. Bunun üzerine İbn Abbas (ra): Sana çelişkili gibi gelen âyetleri söyle, dedi. Adam dedi ki: Allah'ın Kur'ân'da şöyle dediğini okuyorum:

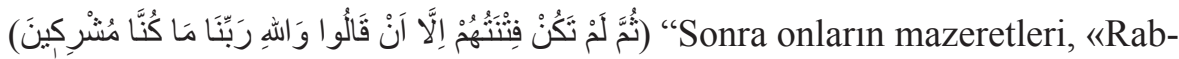
bimiz Allah'a andolsun ki biz ortak koşanlar olmadık» demekten başka bir şey

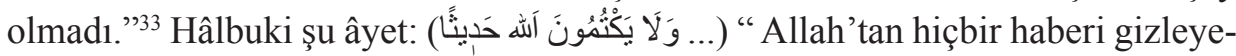
mezler" ${ }^{34}$ demektedir. Oysa önceki âyette onların müşrik olduklarını gizledikleri haber verilmişti.

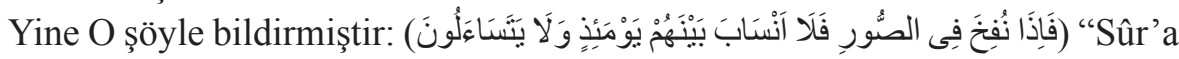
üflendiğinde, artık ne aralarındaki akrabalık bağları işe yarayacak ne de birbirle-

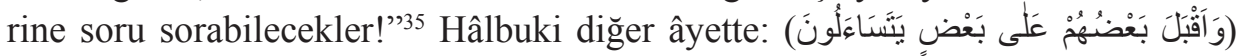
"Birbirlerine dönüp sorarlar" demektedir. ${ }^{36}$

$\mathrm{O}$, şu âyette önce yerin sonra da göğün yaratıldığını haber veriyor:

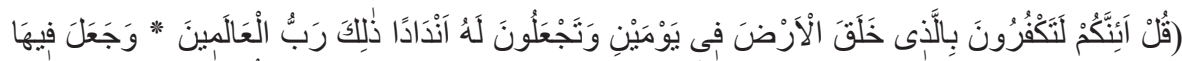

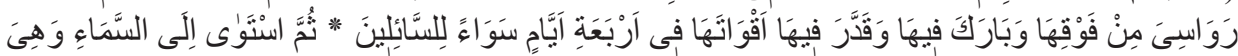

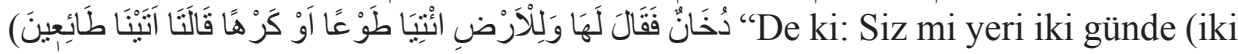
devirde) yaratanı inkâr ediyor ve O'na ortaklar koşuyorsunuz? O, âlemlerin Rabb'idir. O, yeryüzünde yükselen sabit dağlar yarattı, orada bolluk ve bereket meydana getirdi ve orada rızıklar takdir etti. (Yeryüzünün ve barındırdığı şeylerin yaratılış müddetinden) soranlar için tam olarak dört günde (bütün bunları meydana getirmiştir). Sonra duman hâlinde bulunan göğe yöneldi; ona ve yeryüzüne, «İsteyerek veya istemeyerek gelin» dedi. İkisi de, «İsteyerek geldik» dediler." ${ }^{37}$

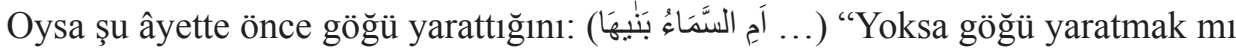
zor?"38 Biraz sonrasındaki âyette de, göğün ardından yeri yarattığını haber veri-

32 İbn Hacer el-Askalânî (v. 852/1449), konuyla ilgili benzer rivâyetlerde isminin açıkça geçmesine dayanarak o kişinin sonradan Hâricilerin Ezârika kolunun reisi olan Nâfi ‘ b. el-Ezrak (v. 65/685) olmasının kuvvetle muhtemel olduğunu zikretmiştir. Fethü'l-Bârî bi-şerhi Sahîhi'l-Buhârî, 13 c., Kâhire, el-Matbaatü'l-hayriyye, 1319-1329 h., C: VIII, s. 393.

33 En'âm 6/23.

34 Nisâ 4/42.

35 Mü'minûn 23/101.

36 Sâffât 37/27; Tûr 52/25.

37 Fussilet 41/9-11.

38 Nazi'ât 79/27. 


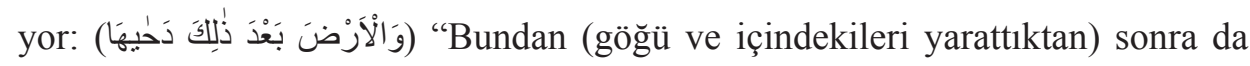
yeryüzünü döşeyip yaydı." ${ }^{39}$

Ayrıca O, birçok yerde, (... Aوكَانَ الهُ (Allah şöyle idi” buyuruyor. Şu anki durumu nedir ki böyle diyor?

İbn Abbas (ra) bu sorulara sırayla şöyle cevap verdi:

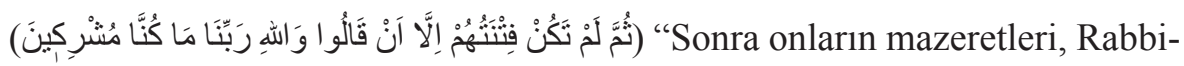
miz Allah'a andolsun ki biz ortak koşanlar olmadık, demekten başka bir şey ol-

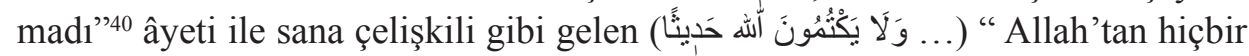
haberi gizleyemezler"41 âyetinin manası şudur: Müşrikler kıyâmet günü olup bitenleri görünce; o gün Allah'ın Müslümanları affettiğini ve şirkten başka bütün günahları bağışladığını gördüklerinde belki bir ümit bağışlanacaklarını umarak dünyada iken müşrik olduklarını inkâr ederek: "Rabbimiz Allah'a andolsun ki biz müşrikler değildik" diyecekler. Bunun üzerine Allah Teâlâ onların ağızlarını mühürler. Artık elleri ve ayakları onların yapmış olduklarını haber verir. İşte " $O$ gün, inkâr eden ve Resûlullah'a isyân edenler yerin altında kaybolmayı temenni ederler ve hiçbir haberi gizleyemezler." «r

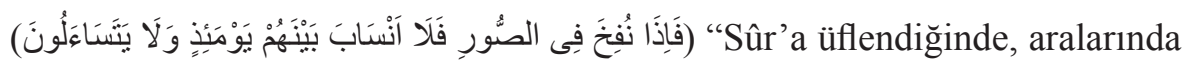
ne akrabalık bağları işe yarar ne de birbirlerine soru sorabilirler!" 43 âyetiyle sana

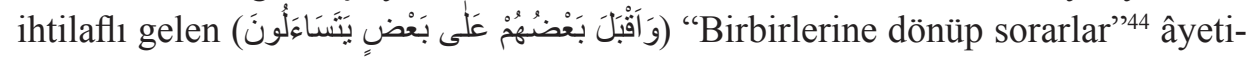
nin anlamı şudur: Birinci “Sur'a üfürüldüğü zaman Allah'ın diledikleri dışında gökte ve yerde olan her şey ölür." ${ }^{45}$ İşte o anda aralarında akrabalık bağları kalmaz, birbirlerine soru da soramazlar. Sonra ikinci kez "Sur'a üflendiği zaman birden ayağa kalkıp etraflarına bakınırlar." ${ }^{\text {46 }}$ Bundan sonra birbirlerine gelip soruşurlar.

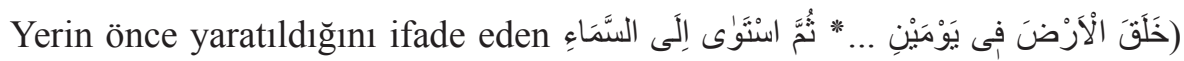

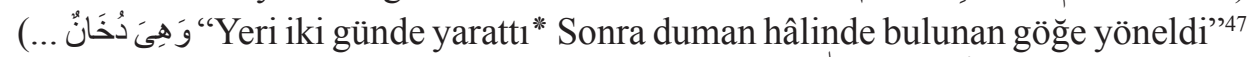

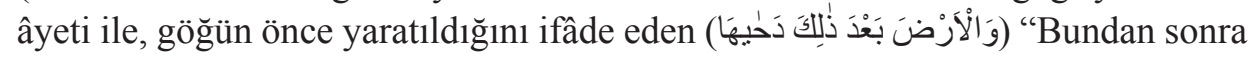

39 Nazi'ât $79 / 30$.

40 En'âm 6/23.

41 Nisâ $4 / 42$.

42 Nisâ $4 / 42$.

43 Mü'minûn 23/101.

44 Sâffât 37/27; Tûr 52/25.

45 Zümer 39/68.

46 Zümer 39/68.

47 Fussilet $41 / 9$ ve 11. 
da yeryüzünü döşeyip yaydı"48 âyeti de ihtilaf etmez. Zira bunların manası şudur: İlk âyet, gökyüzü henüz daha duman halinde iken Cenâb-1 Hakk'nn önce yeryüzünü iki günde yarattı̆̆ııı, sonra göğe yönelip onu yedi kat olarak yaratıp düzene koyduğunu bildirir. İkinci âyet ise, Cenâb-1 Hakk'ın yeri yaratıp, göğü de yedi kat olarak düzenleyip yarattıktan sonra yeryüzünü döşediğini yani orada dağlar, nehirler, ağaçlar, denizler ve rızıkları yarattığını haber vermektedir.

Allah Teâlâ'nın (وكَانَ اللهُ ... (وكُ) sözü ise şu anlama gelir: “Allah nasıl ise öyle daimdir. O, ezelde Azîz, Hakîm, Alîm, Kadîr olduğu gibi ebediyen de öyle devam eder." Artık hangi âyetler sana çelişkili gibi geliyorsa, onların cevabı bu anlattıklarıma benzer. Şüphesiz ki Allah Teâlâ hangi âyeti indirdiyse illa irâde ettiği doğru manaya isâbet etmiştir. Fakat insanların çoğu bunu bilmezler. ${ }^{49}$

İbn Abbas (ra)'ın müşkil âyetlerin çözümünde başlattığı bu faaliyet kendisinden sonra da devam etmiş̧ir. Müfessirler, zâhiren birbiriyle müteârız gibi görünen âyetlere dair insanların zihinlerine takılan problemleri çözmüşler, bundan sonra da ulema yeni çıkan problemlere karşı çözümler üretmeye devam edeceklerdir.

\section{Kur'ân-ı Kerim'de İhtilaflı Gibi Görünen Âyetler Bulunmasının Sebepleri}

Allah Azze ve Celle, Kur'ân-1 Kerim'ini açık bir Arapça dille indirmiştir. ${ }^{50}$ Kullara da onu düşünmelerini emretmiştir. ${ }^{51}$ Sahâbe bu emri gerçekleştirmek için anlamadıkları âyetleri Resulullah (as)'a sorup hallediyorlardı. Sonra tâbiîn, tebe-i tâbiîn ve sonraki asırlarda Kur'ân-1 Kerim etrafındaki müşkil sorular çoğaldı. Kur'ân-1 Kerim'i düşünmeye dair ilâhî emrin bulunması, Arap olmayanlardan İslâm'a girenlerin çoğalması, insanların kültür ve coğrafya farklılıklarının farklı anlayışlara sebep olması, İslâm'a hasım olanların ortaya attıkları şüpheler ve benzeri durumlar bu soruların artma nedenlerinden sayılabilir. Bu müşkil soruların önemli bir bölümü "aralarında çelişki var olduğu sanılan âyetleri” teşkil eder. Âlimler bu konuyu ele alıp bu tür âyetleri açıklamışlar; Kur'ân nasları arasında çatışmanın muhal olduğunu ortaya koymuşlardır. İhtilaf ve tenâkuz gibi zihne ârız olan âyetler hakkında ne varsa hepsinin vehim ve zandan ibaret olduğunu ifade etmişlerdir. Bu zannın birtakım sebepleri vardır. Zerkeşî ve Süyûtî ihtilaf

48 Nazi'ât 79/30.

49 Ebû Bekr Abdürrezzâk b. Hemmâm es-San ânî (v. 211/826-27), Tefsîrü 'l-Kur'ân, nşr. Mustafa Müslim Muhammed, 3 c., Riyad, Mektebetü'r-rüşd, 1410/1989, C: I, s. 160-162'den naklen es-Süyûtî, el-İtkân, C: II, s. 724-725. Süyûtî bu rivâyetin aslının Sahîh'de olduğunu da zikreder. Bkz. Ebû Abdillâh Muhammed b. İsmâîl el-Buhârî (v. 256/870), el-Câmi 'u's-sahîh, nşr. Mustafa Dîb el-Bugâ, 7 c., Beyrut, Dâr'ü-bni Kesîr, 1410/1990, “Tefsîr”, 301.

50 Mâide 5/67.

51 Nisâ 4/82. 
sebeplerini beş tane olarak zikrederler. Kıraat farklılıklarını da buna ilave ederek bu sebepleri altı olarak sayabiliriz. Şimdi bu sebepleri misalleriyle birlikte ele alalım:

\section{Haber Verilen Şeyin Farklı Merhalelerde Bulunması:}

Kur'ân-1 Kerim'de Âdem (as)'ın yaratılışı haber verilirken, onun yaratıldığı madde birbirinden farklı şekillerde ifade edilmiştir. Bu âyetlerin bazısında Âdem

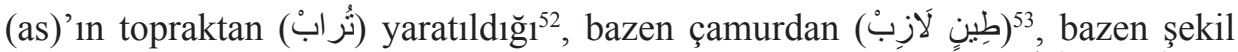

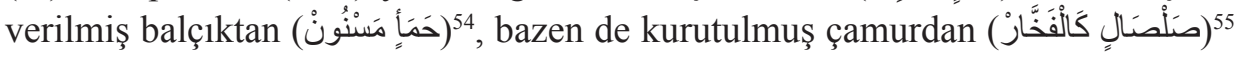
yaratıldığı anlatılmaktadır. Bu lafızlar birbirinden farklı anlamda oldukları için aralarında ilk anda teâruz izlenimi doğabilir. Âdem (as)' 1 n yaratılışını haber veren bu âyetler zahiren birbirinden farklı olsa da hakikatte bunlar arasında bir çelişki söz konusu değildir. Zira bu âyetlerde Âdem (as)'ın yaratıldığı toprağın çeşitli vasıfları ve halleri; yaratılışın evreleri zikredilmektedir. Bununla birlikte hepsinin özü aynıdır yani topraktır. ${ }^{56}$

Ayrıca Kur'ân-1 Kerim'de Hazreti Mûsâ'nın asâsının bir mucize eseri olarak yılana dönüştüğü anlatılmaktadır. Bu asâ, bazen küçük bir yılana (جَانُن (جَانُ) benzetilmiş; bazen de büyük bir yılan (تُعََْنْ) diye isimlendirilmiştir. Asânın aynı anda hem küçük hem de büyük yılan olarak adlandırılması ilk bakışta çelişkili gibi görünse de hakikatte aralarında zıtlık yoktur. Çünkü asâ, büyük bir ejderha olarak yılana dönüşmektedir. Bu cüssesine rağmen hantal değildir bilakis küçük bir y1lan gibi hızlı hareket etmektedir. ${ }^{57}$

\section{Konu (Mevzu) ve Yer Farklılığı:}

Şu âyet-i kerimede inkârcıların sorgu suale tabi tutulacakları bildirilmiştir:

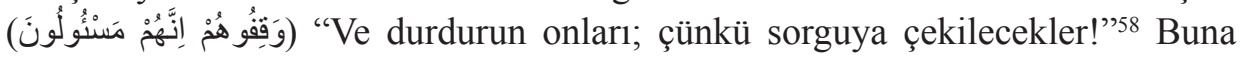
benzer anlamdaki diğer bir âyette ise, ümmetlere ve peygamberlerine kıyâmet

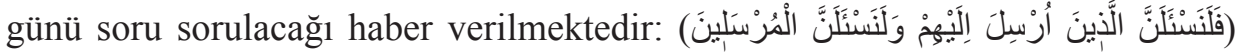
"Elbette kendilerine peygamber gönderilen kimseleri de, gönderilen peygamber-

52 Sâffât 37/11.

53 Sâd 38/71.

54 Hicr 15/26.

55 Rahmân 55/14.

56 ez-Zerkeşî, Ebû Abdillâh Bedrüddîn Muhammed b. Bahâdır (v. 794/1392), el-Burhân fî̀ 'ulûmi'l-Kur'ân, nşr. Muhammed Ebü'l-Fazl İbrâhîm, 4 c., 3. bs., Kâhire, Mektebetü dâri’t-türâs, 1404/1984, C: II, s. 54-55.

57 ez-Zerkeşî, a.g.e., C: II, s. 55.

58 Sâffât $37 / 24$. 
leri de mutlaka sorgulayacağız"59 Her iki âyet de kıyâmet günü soru sorulacağını ifade ederken şu âyette ise hiç kimseye soru sorulmayacağı beyan edilmektedir:

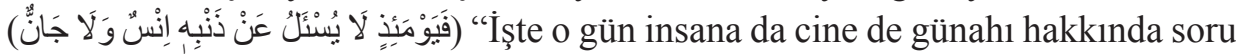
sorulmaz" ${ }^{\prime 60} \mathrm{Bu}$ âyetler arasındaki zahirî teâruzun sebebi, bazılarına göre konu farklılı̆̆

Zerkeşî’nin naklettiğine göre Şafî fakîhlerinden Halîmî (v. 403/1012) soru sorulacağını ifade eden ilk iki âyet ile soru sorulmayacağını ifade eden son âyetin arasında konu farklılığına değinerek bunları şöyle uzlaştırır (tevfîk/te'lîf): "İlk âyette geçen soru, müşriklere yönelik olup Allah'a iman edip etmedikleri sorusudur. İkinci âyetteki soru, ümmetlere yönelik olarak peygamberlerine iman edip etmedikleri, peygamberlere yönelik olarak da ümmetlerinin kendilerine iman edip etmedikleri sorulacaktır. Son âyette sorulmayacağ 1 ifade edilen soru ise, inkârcılara yönelik olarak şeriat ve amelî konulara ait sorulardır (furû)." ${ }^{" 61}$

Süyûtî'nin nakline göre, diğer âlimler bahsedilen âyetler arasındaki zahirî ihtilafi yerlerin değişikliği ile te'vil etmişlerdir. Çünkü kıyâmette çok duraklar vardır. Bu yerlerin bazısında suale tabi olurlarken bazısında onlara sual sorulmaz. $^{62}$

Şu âyetler arasındaki zahirî teâruz ise konu değişikliğiyle te'lif edilmiştir:

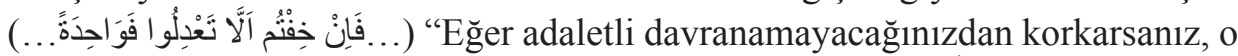

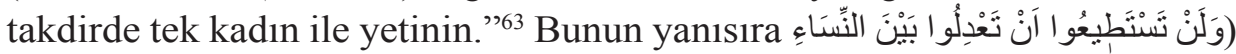
(... Ne kadar uğraşırsanız uğraşın, kadınlar arasında âdil davranmaya güç yetiremezsiniz" ${ }^{64}$ buyurulmaktadır. İlk âyetten, eşler arasında adaletli davranmanın mümkün olduğu anlaşılmaktadır. İkinci âyette ise bunun mümkün olmadı $\breve{g} 1$ ifade edilmektedir.

Zerkeşî bu iki âyeti şöyle uzlaştırır: İlk âyetteki adalet, eşlerin haklarını yerine getirmek hususunda eşler arasında adaletli davranmaktır ki bunun yerine getirilmesi mümkündür. İkinci âyetteki adalet ise, kalbin meylidir. Eşlerin bazısına meyledip bazısına meyletmemek insanın gücü dâhilinde ve elinde değildir. ${ }^{65}$

\footnotetext{
59 A'râf 7/6.

60 Rahmân 55/39.

61 ez-Zerkeşî, a.g.e., C: II, s. 55.

62 es-Süyûtî, el-ìtkân, C: II, s. 730.

63 Nisâ 4/3.

64 Nisâ 4/129.

65 ez-Zerkeşî, a.g.e., C: II, s. 58.
} 


\section{Aynı Fiilin Kullanım Bakımından Veya Faile İsnat Bakımından Farklı Olması:}

Bir fiil herhangi bir âyette fâiline nispet edildikten sonra aynı âyette veya ayrı bir âyette başka bir fâile isnat edilerek gelmektedir. Bu durum, fiilin kullanım yönlerinin farklı olmasından kaynaklanmaktadır. Bu ise âyetler arasında ilk anda çelişki görünümüne sebep olabilmektedir. Birkaç örnekle bunu açıklayalım: فَزَ) (Savaşta onlar1 siz öldürmediniz bilakis onları Allah öldürdü. Attığın zaman da sen atmadın bilakis Allah attı."

Müminler Bedir Savaşı'nda müşriklerin bir kısmını öldürmüş, bir kısmını da esir almışlardı. Savaştan geri dönerlerken ashâb-1 kiram içinde "şöyle öldürdüm, şöyle esir aldım" diye iftihar edenler oldu. Bunun üzerine yukarıdaki âyet-i kerime nazil oldu. Âyetin iniş sebebinden de anlaşılacağ 1 üzere müminler için öldür-

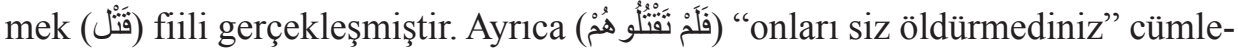
sinden önce hazfedilen şart cümlesi, müminlerin kâfirleri öldürdüğüne de delalet etmektedir. Zira mahzuf olan şartla birlikte cümlenin takdiri şöyledir: "Eğer kâfirleri öldürmenizle iftihar ediyorsanız biliniz ki onları siz öldürmediniz.” Mü-

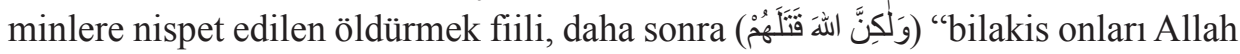
öldürdü" cümlesiyle müminlerden nefyedilmek sûretiyle Allah'a isnat edilmiştir. ${ }^{67}$ $\mathrm{Bu}$ manalar hakikatte birbiriyle çelişmez. Zira öldürme fiili müminlere kesb ${ }^{68}$ bakımından nispet edilmiş, yaratma bakımından ise onlardan nefyedilmiştir. Bundan dolayı âlimlerin çoğunluğu demiştir ki: Fiiller, Allah Teâlâ tarafından yaratılmış, kullar tarafından kesbedilmiştir. Öyleyse fiili bir yönden nefyetmek, başka bir yönden onu ispat etmeye zit değildir. ${ }^{69}$ Buna göre öldürme fiilinin müslümanlara isnat edildikten sonra onlardan nefyedilmesi hakikatte bir çelişki teşkil etmemektedir.

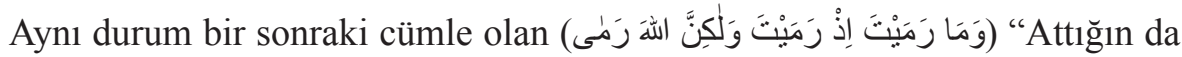
sen atmadın, fakat Allah attı"70 âyetinde de söz konusudur. Atmak رَمَّمَ filili önce

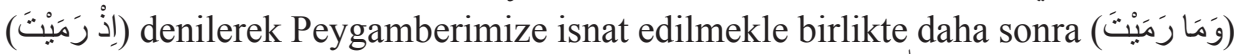
denilerek ondan nefyedilmiştir. Sonrasında ise (وَلكِنَّ اللَّة رَمَى) "Fakat Allah attı"

66 Enfâl 8/17.

67 Ebussuûd b.Muhyiddîn Muhammed (v. 982/1574), İşâä̈l'- 'akli's-selîm ilâ mezâya 'l-Kitâbi'lKerîm, nşr. Abdülvasîf Muhammed, 5 c., Kâhire, Darü'l-'usûr, 1347 h. (Darü'l-fikr ofset), C: II, s. 351-352.

68 Kesb: Kulun iradesini kullanarak fiili işlemeye yönelmesidir. Ebû 'Azbe, Hasan b. Abdülmuhsin (v. 1172/1759), er-Ravzatü'l-behiyye fìmâ beyne'l-Eşâ 'ire ve'l-Mâtürîdiyye, Haydarâbâd, Meclisü dâireti'l-me'ârif, 1322/1905, s. 26.

69 ez-Zerkeşî, el-Burhân, C: II, s. 59.

70 Enfâl 8/30. 
denilmek sûretiyle Allah'a isnat edilmiştir. Hem Resulullah'a hem de Allah'a isnat edilen fiil ayn ${ }^{71}$ olmakla birlikte her ne kadar zâhirde bir ihtilaf gözükse de gerçekte aralarında bir çelişki yoktur. Çünkü atmak (رَمْي) fiili, Resulullah’a kesb bakımından nispet edilmiş, Allah'a ise yaratma bakımından isnat edilmiştir.

\section{Kelimenin Hakîkat ve Mecaz Yönünden Farklı Anlamda Olması:}

Aynı kelime ile bir yerde mecâzi anlam, diğer yerde hakiki anlam kastedilir. $\mathrm{Bu}$ durum bilinmezse iki cümle arasında ihtilaf var olduğu sanılabilir. Fakat hakiki ve mecâzi kullanım bilinirse akla takılan tenâkuz zannı ortadan kalkar. Şu

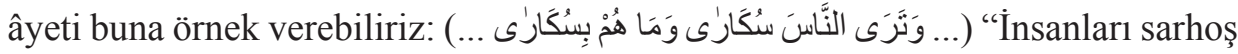
görürsün; hâlbuki onlar sarhoş değillerdir." 72 Zerkeş̂’ye göre bu âyette iki defa zikredilen (سُكَارنى) "sarhoşlar" kelimesi hakîkat ve mecaz yönünden farklılık arz eder. Birinci cümledeki (سُكَارنى) kelimesi mecaz; ikinci cümledeki ise hakîkattir. Buna göre âyetin anlamı şöyledir: "Kıyâmetin dehşetinden dolayı o gün insanları sarhoş görürsün.” Buradaki sarhoşluk mecâzidir. "Oysa onlar şarap içip de sarhoş değillerdir". Buradaki sarhoşluk ise hakikidir ${ }^{73}$

\section{Birden Fazla Anlamı Olan Kelimenin Akla İlk Gelen Manasının Tercih Edilmesi}

Bazen âyette geçen kelime birden çok manaya gelebilir. Akla ilk gelen fakat mütekellim tarafından kastedilmeyen manasını düşündüğümüzde, diğer âyetlerle arasında ihtilaf olduğu sanılabilir. Fakat o kelimenin diğer anlamını kastettiğimiz durumda bu âyetle diğer âyet arasındaki çelişki durumu ortadan kalkar. Şu iki

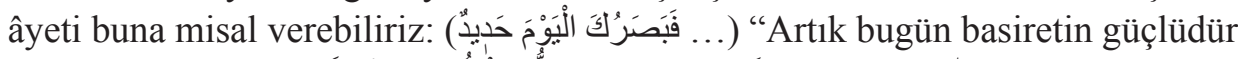

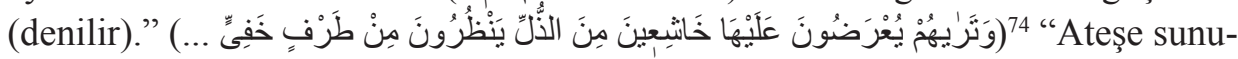
lacakken onların zilletten başlarını öne eğmiş, göz ucuyla gizli gizli baktıklarını görürsün." 75 İlk âyette geçen basar (بَمَرَ) kelimesi Arap dilinde hem göz görmesi hem de kalp görmesi manasına gelir. Burada göz görmesi manasını kastettiğimizde âyet şu anlama gelir: “Artık bugün gözün keskindir.” İkinci âyette ise onların göz ucuyla gizli gizli baktıkları ifade edilmiştir. Bu durumda iki âyet arasında ilk anda akla bir çelişki zannı gelebilir.

Zerkeşî, Kutrub'dan (v. 206/821) naklederek bu iki âyet arasındaki işkâli şöyle çözümler: Birinci âyetteki basar kelimesinden maksat ilim ve basirettir. Yoksa

71 ez-Zerkeşî, a.g.e., C: II, s. 60.

72 Hac 22/2.

73 ez-Zerkeşî, a.g.e., C: II, s. 60.

74 Kâf 50/22.

75 Şûrâ 42/45 
göz görmesi değildir. Buna göre âyetin anlamı şudur: "Artık bugün ahireti tanıman kuvvetlidir, ona dair bilgin kesindir." Böylece zahiri ihtilaf ortadan kalkmış olur. Ebû Ali el-Fârisî (v. 377/987) demiştir ki: Nitekim âyetin bundan önceki:

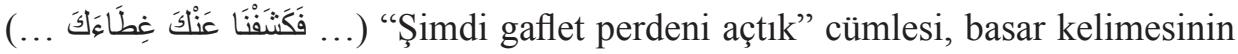
ilim ve basiret anlamına geldiğine delalet eder. ${ }^{76}$ Zira gaflet perdesi gözle alakalı değil, ilim ve basiretin mahalli olan kalple alakalıdır.

\section{Kıraat Farklılıkları:}

Bazen aynı âyette birden çok kıraat bulunması ilk anda zihne bir ihtilaf vehmi

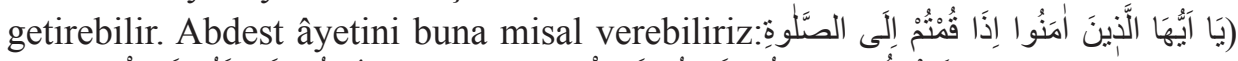
Ey iman edenler! Namaza kalkacağınız zaman yüzlerinizi, dirseklere kadar ellerinizi ve başlarınızı mesh edip her iki topuğa kadar da ayaklarınızı yıkayın." ${ }^{.77} \mathrm{Bu}$ âyette geçen (اَرْجُجْلَ) kelimesi, mütevâtir kıraate göre hem nasb hem de cer ile okunmuştur. Nasb kıra-

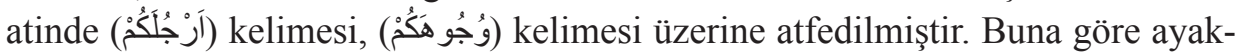
ların yüzler gibi yıkanması emredilmiştir. Cer kıraatinde ise, (أَرْجُجْكُمْن kelimesi ( (رُوُُسِكُْْ üüzerine matuf olduğu için akla ilk anda çıplak ayakların meshedileceği zannı gelebilir. Oysa nasb kıraatiyle cer kıraati arasında hakikatte bir ihtilaf söz konusu değildir. Süyûtî, iki kıraati birbiriyle uzlaştırma bâbında âlimlerin şu cevabını nakletmiştir: "Nasb kıraati ayakların yıkanmasını, cer kıraati ise mestler üzerine mesih yapılmasını beyan etmektedir." 78 Bununla birlikte Resulullah (as)'ın meşhur sünneti ve sahabenin ameli de ayakların abdestte yıkanması gereken azalardan olduğuna delalet etmektedir. ${ }^{79}$ Ayrıca şeriatta, bir azanın meshi için sınır belirtilmemiştir. Hâlbuki çıplak ayakların meshedileceğini söylediğimiz takdirde (إلَى الْكَعْبَيْنِ sözüyle meshe sınır getirilmiş olur ki ${ }^{80}$ bunun şeriatta geçerliliği yoktur.

\section{Müşkilliği Giderme Yolları}

Âyetler arasında görünen teâruz hakiki değildir. Çünkü kat'î delillerde zanna yer olmayıp bu delillerin kendi aralarında teâruz etmesi muhaldir. Recep Abdülfettah demiştir ki: 'Kur'ân-1 Kerim'de tenâkuz zannettiğin şeyi düşün. Şayet

76 Kâf 50/22. ez-Zerkeşî, a.g.e., C: II, s. 61.

77 Mâide 5/6.

78 es-Süyûtî, el-ittkân, C: II, s. 734.

79 Şeyhzâde, Muhammed b. Muslihiddin Mustafa el-Kocevî (v. 950/1543), Hâşsiyetü Şeyhzâde 'alâ Tefsîri'l-Kâdı'l-Beyzâvî, 4 c., İstanbul, Hakîkat kitâbevi, 1415/1994, C: II, s. 198

80 el-Konevî, Ebü'l-Fidâ İsmâil Vehbî b. Muhammed (v. 1195/1781), Hâşiyetü'l-Konevî 'alâ Tefsîri'l-Beyzâvî, 7 c., İstanbul, el-Matbaatü'l-'âmire, 1286 h. (İstanbul, el-Mektebetü'l-Mahmûdiyye ofset, ts.), C: III, s. 313. 
anlayamazsan ilimde kökleşenlerin yoluna uyarak de ki: "Ona iman ettik. Hepsi Rabb'imizin katındandır. ${ }^{81}$ Böylece zihnine gelen o müşkili inzâl edene 1smarla. Kusuru kendi bilgin ve anlayışında ara. Kur'ân'da tenâkuz olmadığını bil."»2 Abdülfettâh, Kur'ân ve diğer şer'î delillerde teâruz olmadığını vurgulamak için İbn 'Useymîn'in (1929/2001) şu sözünü de nakleder: "Şu önemli kaideyi bilmemiz gerekir: İki kat'î delilin çelişmesi asla mümkün değildir. Bu deliller ister Kur'ân'da, ister sünnette, isterse aklî olsun farketmez. Çünkü iki delil gerçekten çelişecek olsa biri sabit, diğeri nefyedilmiş olur. Şayet nefyedildiğini söylersek o zaman ondan kat'î delil ismi kalkmış olur." ${ }^{\text {83 }}$

İhtilaflı gibi görünen âyetlerdeki işkâli gidermek için âlimler te’lîf (uzlaştırma), tahsis veya nesih yoluna başvurmuşlardır. Zerkeş̂’nin işkâli gidermek hususunda misaller vererek yaptığı açıklamalardan bunu anlıyoruz. ${ }^{84}$ İtikât ve ahlâkla ilgili müsskil âyetlerde uzlaştırma ve yorumlama yoluna müracat edilirken, ahkamla ilgili konulardaki müsskil âyetlerde ise tahsis veya nesih yoluna gidilmektedir. ${ }^{85}$ Orijinallik içermesi hasebiyle Ebussuûd Efendi'nin bu yöntemlerle işkâli nasıl giderdiğini görmek için her bir kısma onun tefsirinden birkaç misal verelim.

\section{Te'lif (Uzlaştırma) Yolu:}

Birbiriyle ihtilaflı gibi sanılan âyetler arasında işkâli çözümlerken çoğunlukla bu âyetleri uzlaştırma yöntemine başvurulur. Bundan önceki konuda Kur'ân-1 Kerim'de ihtilaflı gibi görünen âyetler bulunmasının sebeplerini açıklarken buna misaller vermiştik. Şimdi Ebussuûd Tefsirinden iki misal verelim:

Sâlih (as)'ın kavmi Semûd'un helak edilmesiyle ilgili müşkil: Sâlih (as)'1n peygamber olarak gönderildiği Semûd kavmi, başta şirk olmak üzere işledikleri zulümler sebebiyle helak edilmişti. Ebussuûd Efendi, Kur'ân-1 Kerîm'de onların helakının iki farklı şekilde olduğunu zikreder. Zira A'râf âyetinde onların şiddetli bir zelzele ile helak edildiği haber ve-

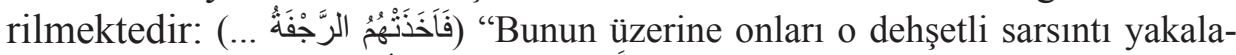
d..”86 Hûd sûresinin (... Zulmedenleri de o korkunç ses

81 Âli İmrân 3/7.

82 Receb Abdülmunsif Abdülfettâh, "Menhecü'ş-şeyh İbn 'Useymîn fî beyâni müşkili'l-Kur'ân”, Nedvetü cuhûdi'ş-Şeyh Muhammed el-'Useymîn el-'ilmiyye, Kasîm Üniversitesi, 1431/2010, s. 429.

83 Receb Abdülfettâh, a.g.e., s. 429-430.

84 ez-Zerkeşî, el-Burhân, C: II, s. 48-50.

85 Adem Yerinde, Diyanet İslam Ansiklopedisi [DİA] ,"Müşkilü'l-Kur'ân”, İstanbul, 2006, C: XXXII, s. 165 .

86 A'râf $7 / 78$. 


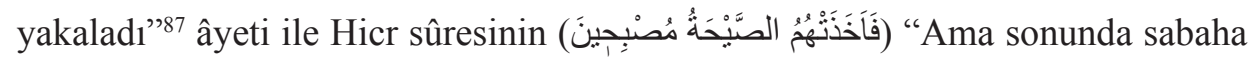
girerlerken korkunç ses onları da yakaladı!" sesle helak edildikleri anlatılmaktadir.

Müfessirimiz bu âyetler arasındaki işkâli te'lif etme (uzlaştırma) yoluyla çözümlemiştir. Şöyle ki, emareleri başladıktan üç gün sonra va'dolunan azap geldiği zaman önce Cibrîl (as)'ın korkunç ve uğultulu sesi onları yakaladı. Ebussuûd'un zikrettiği diğer bir görüşe göre gökyüzünden üzerlerine bir ses geldi. Bu ses, bütün yıldırımların ve yeryüzündeki herşeyin sesinden daha şiddetliydi. ${ }^{89}$ Âlûsî (v. 1270/1854) bunu Katâde'den (v. 117/735) rivâyetle, "bütün ses tariflerinin dışında korkunç bir ses” diye tefsir eder. ${ }^{90}$ Müellif, Cibrîl (as)'ın sesinden sonra onları büyük bir zelzelenin yakalamış olabileceğini söylemektedir. Zira bu güçlü ses, şiddetli bir şekilde havanın dalgalanmasına sebep olmuştur. Bu şiddetli hava dalgalanması ise, sürekli temas halinde olduğu yerin sarsıntısına neden olmuştur. Sonuç olarak Ebussuûd'un yaptığı bu açılamalar ışığında söz konusu âyetler arasında teâruz olmadığı anlaşılmaktadır. Nitekim Âlûsî de "Bu âyetler arasında teâruz yoktur" diyerek bunu açıkça beyan etmiştir. ${ }^{91}$

Mûsâ (as)'ın asâsıyla ilgili âyetlerdeki müşkil: Ebussuûd Efendi, Mûsâ (as)'ın asasının farklı yılan türlerine dönüşmesiyle ilgili bir müşkili de konu eder ve bunu cevaplar. Bu müşkil şu mukadder sorudan ibarettir: Allah Teâlâ Kur'ân-1 Kerîm'de Hazreti Mûsâ'nın asâsını bazen yılan (حَيَّة) ismiyle zikretmektedir:

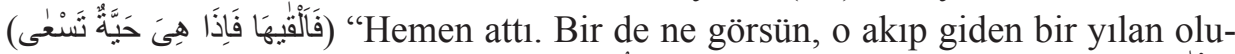

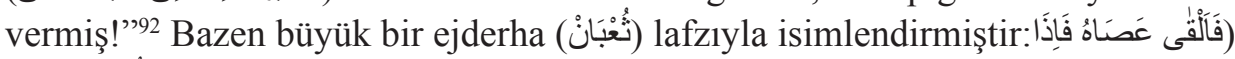

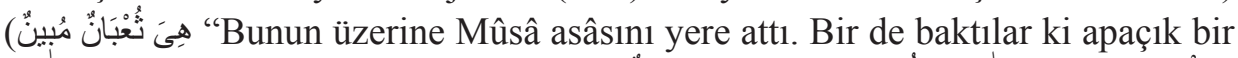

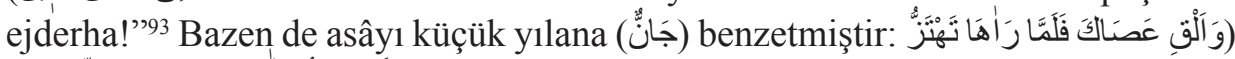

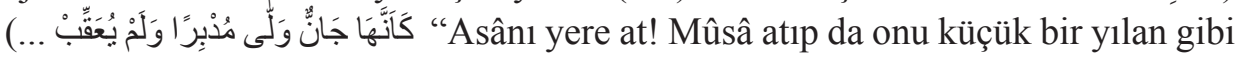
kımıldanır görünce arkasına bakmadan dönüp kaçt1 ..."

\section{Hûd 11/67.}

88 Hicr $15 / 83$.

89 Ebussuûd, İşâd, C: III, s. 48.

90 el-Âlûsî, Ebü's-Senâ Şihâbüddîn Mahmûd b. Abdillâh (v. 1270/1854), Rûhu'l-me 'ânî fì tefsîri'l-Kur'âni'l- 'Azîm ve's-Seb 'i'l-Mesânî, 15 c., Beyrut, Dârü ihyâi't-türâsi'l-'Arabî, ts., C: XV, cüz 29, s. 40.

91 el-Âlûsî, C: XV, cüz 29, s. 40.

92 Tâhâ 20/20.

93 A'râf 7/107.

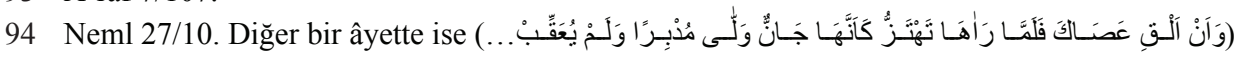
"Değneğini yere at, diye nida oldu. Mûsâ, değneğini (yere attıktan sonra) bir yılanmış gibi süratle hareket eder görünce, arkasına bakmadan dönüp kaçtı” buyurulmaktadır. Kasas 28/31. 
İlk âyette geçen (حَََّنَ) kelimesi cins isimdir. Küçük-büyük, erkek-dişi bütün

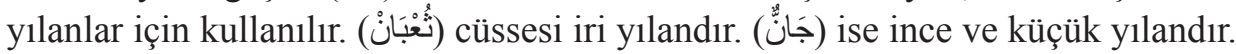
Aralarında ilk bakışta bir zıtlık olduğu sanılabilir. Ebussuûd Efendi bu müşkili iki şekilde cevaplamıştır:

1. Cevap: Mûsâ (as), asâsını yere attığı zaman, asâ kalınlığında sapsarı bir y1lana dönüşüverdi. Bundan dolayı asâ, bazen bu haliyle tasvir edilerek küçük yılana (جَانٌ benzetildi. Daha sonra giderek şişti ve ejderha halini aldı. Bazen bu

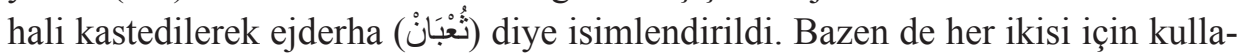
nılan yılan (حَيَّ) ismiyle zikredildi.

2. Cevap: Asâ ilk yere atıldığı zaman zaten koskoca bir ejderha (تُعَّْنْ) olmuştu. Bununla birlikte çevik olması ve hızlı hareket etmesinden dolayı küçük bir yılana (جَ) benzetilmiştir. Yoksa cüssesinin küçük olması bakımından küçük bir y1lana benzetilmemiştir.

Müfessirimiz, bu ikinci manayı kıssanın anlatıldığı makama daha uygun bu-

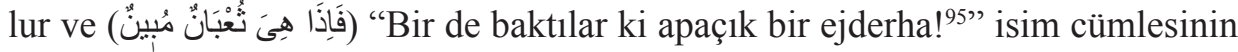
de bunu açık olarak ifade ettiğini belirtir. Çünkü cümlenin başındaki izâ-i mufâcee ${ }^{\text {q }}$ asânın hızlı bir şekilde ejderhaya (تُُْْبَانْ) dönüştüğüne; cümlenin isim cümlesi olarak gelmesi de, asâdaki ejderhalık vasfinın her zaman devam ettiğine ve asânın sanki aslında ejderhaymış gibi olduğuna delalet etmektedir. ${ }^{97}$

\section{2) Tahsis Yolu:}

Ebussuûd Efendi, ilk bakışta birbiriyle mütenâkız gibi görünen âyetler arasındaki işkâli bazen de "tahsis" yoluyla gidermiştir. Şu kadar var ki, müfessirimiz Hanefî usûlcülerin yolunu takip ederek "tahsis" ile "âmmı nesheden"i birbirinden ayrı ele almıştır. Fıkıh usulünün konusu olduğu için müellif bu şartları açıkça zikretmese de, onun ifadelerinden her ikisi için de birtakım şartlar bulunduğunu anlıyoruz. Ayrıca müellifin, tahsisten ayrı olarak ele aldığ 1 "umûmun neshi" konusunun, diğer usûlcüler tarafindan "tahsis" diye isimlendirdikleri anlaşılmaktadır. ${ }^{98}$ Şimdi Şeyhülislam'ın "tahsis" yoluyla işkâli çözümlemesine bir örnek, sonra da "umûmu neshetme" yoluyla çözümlemesine bir örnek verelim.

95 A'râf 7/107; Şu'arâ 26/32.

96 İzâ-i mufâcee: Sadece cümle-i ismiyyeye dâhil olup cümle başında gelmeyen ve cevaba ihtiyaç duymayan edattır. el-Külliyyât Mu'cem fi'l-mustalahât ve'l-furûki'l-lugaviyye. Ebü'l-Beka el-Kefevi, Eyyûb b. Mûsâ (v. 1095/1684), nşr. Adnan Dervîş-Muhammed Misrî, 2. bs., Beyrut, Müessesetü'r-risâle, 1419-1998, s. 71.

97 Ebussuûd, İşâd, C: III, s. 457; C: II, s. 283.

98 Ebussuûd, a.g.e., C: IV, s. 71. 


\section{Tahise Örnek: Allah Teâlâ'nın Azap Sözüyle İlgili Müşkil}

Ebussuûd Efendi, Cenâb-1 Hakk’1n şu âyette azgınlığa azapla karşılık vereceğini haber verdiğini söyler.

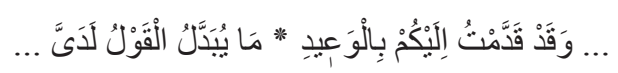

"Muhakkak ki Ben sizi daha önceden (dünyada) azapla tehdit etmiştim. Benim katımda söz değiştirilmez." ${ }^{99}$ Allah Teâlâ, bu tehdidini dünya hayatında göndermiş olduğu kitaplarıyla ve peygamberlerinin diliyle yapmıştır. Öyleyse azgınlık eden kulların âhiret günü boş bahaneler üreterek bu azap tehdidinden kurtulmayı ümit etmemelerini onlara hatırlatmış; sonrasında da bu sözünün değiştirilmeyeceğini söyleyerek bunun değiştirilmesini ümit etmemelerini onlara haber vermiştir. ${ }^{100}$

Azap sözünü değiştirmemekle birlikte bazı günahkârları affetmesi arasında sanki ilk başta bir teâruz varmış gibi görünür. Oysa müfessirimize göre birtakım sebeplerden dolayı bazı günahkârların affedilmesi Allah Teâlâ'nın sözünü değiştirmesi (tebdil) anlamına gelmez. Zira af ve mağfiret âyetleri, azabı tahsis etmiştir. ${ }^{101}$ Yani Şeyhzâde'nin dediği gibi umumî olarak gelen bu azap âyetleri, Allah Teâlâ'nın azap etmeyi dilediği kâfirler ve günahkâr müminler hakkındadır. Büyük günah sahibi müminlerden bazıları ise affa nail olarak umum ifade eden bu âyetin kapsamı dışında tutulurlar. Öyleyse bazılarının affedilmesi sebebiyle, Allah'ın sözünde değiştirme (tebdil) olmamıştır. ${ }^{102}$

\section{Umûmun Neshine Örnek: Kocası Ölen Hamile Kadınların İddetiyle İl- gili Müşkil}

Ebussuûd Efendi, kocası ölen hamile kadınların iddetinin doğum yapmalarıyla mı yoksa dört ay on gün beklemeleriyle mi sona ereceği hususundaki bir müşkili de açıklar. Bakara sûresindeki şu âyet-i kerimede kocası ölmüş olan kadınların iddetinin ister boşanmış olsun isterse hamile olsun dört ay on gün olduğunu belirtir:

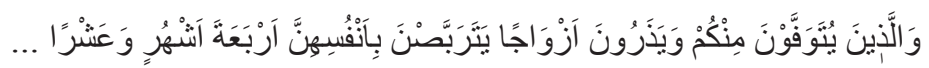

“İçinizden ölenlerin geride bıraktıkları eşleri kendi başlarına (evlenmeksizin) dört ay on gün beklerler." ${ }^{103}$ Fakat sonra nâzil olan Talâk sûresindeki şu âyet-i kerime, yukarıda geçen âyetin umûmiliğini neshetmiştir:

\footnotetext{
99 Kâf 50/28-29.

100 Ebussuûd, a.g.e., C: V, s. 622-623.

101 Ebussuûd, a.g.e., C: V, s. 623.

102 Şeyhzâde, Hâşiye 'ale'l-Beyzâvî, C: IV, s. 288.

103 Bakara 2/ 234.
} 


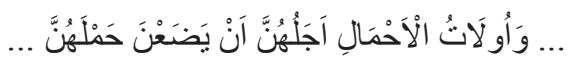

"Hamile olanların bekleme süresi ise, doğum yapmalarıyla sona erer." ${ }^{104}$ Zira müfessirimiz bu âyet-i kerimenin diğer âyetin umûmunu neshedici olduğunu ifade etmiş ve buna tahsis denemeyeceğini beyan etmiştir. Zira tahsisin şartlarından birisi de, tahsis edicinin (muhassıs) sonraki bir zamanda değil aynı zamanda nâzil

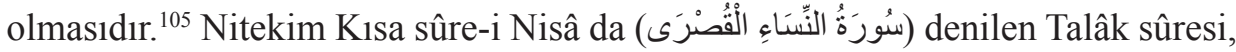
Bakara sûresinden sonra nâzil olduğu için burada tahsis değil umûmun neshi bulunur. ${ }^{106}$

3) Nesih Yolu: Kur'ân-1 Kerim'in bazı âyetleri arasında nâsih-mensuh ilişkisi olduğu Ehl-i sünnet âlimlerinin ittifakıyla sabittir. Nâsih ve mensuhun bilinmesiyle doğru hükme ulaşmak mümkün olur. Süyûtî'nin Ebû İshâk el-İsferâyînî'den (v. 418/1027) naklettiğine göre, aralarında teâruz olan ve hiçbir şekilde aralarını uzlaştırmak mümkün olmayan âyetler tarihî açıdan incelenir. Önceki ile sonraki bilindiği zaman önceki bırakılıp sonraki alınır. Diğeri mensuh olur. Tarihleri bilinmezse ve iki âyetten biriyle amel etmek üzere icmâ süregelmişse bu durumda icmâ ile şu bilinmiş olur ki, amel etmek üzere ümmetin üzerinde ittifak ettikleri âyet nâsihtir. Böylece teâruz ortadan kalkmış olur. ${ }^{107}$

Ayrıca burada şu husus göz ardı edilmemelidir. Zürkânî’nin (v. 1367/1948) dediği gibi iki nas arasında teâruz bulunduğu zaman önce tahsis veya te'vil yollarından birisiyle iki nassı bütünleştirmek gerekir. Ancak bu mümkün olmadığ 1 durumda neshe gidilir. Zira iki delili amel ettirmek, sadece birini amel ettirip diğerini boşa çıkarmaktan daha evladır. Ayrıca nesih olgusu hükümlerde cereyan ettiğine göre hükümlerde de asıl olan kalıcı olmasıdır. ${ }^{108}$

Şimdi nesih yoluyla işkâlin giderilmesine bir örnek verelim. Ebussuûd Efendi, müminlerin harpte iken on kat fazla düşmana karşı sebat etmesini farz k1lan âyetin daha sonra gelen iki kat fazla düşmana sebat etmeyi farz kılan âyetle mensuh olduğunu zikreder. ${ }^{109}$ Şöyle ki, Yüce Allah, kâfirlerle yapılan harpte Re-

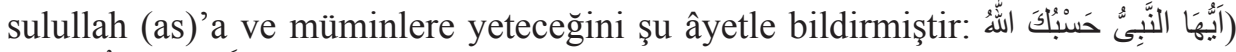
Ey Peygamber! Sana tâbi olan müminlerle beraber Allah sana yeter." "110 Bu âyetten sonra Cenâb-1 Hakk, müminleri kâfirlere karşı harbe

104 Talâk 65/4. Ebussuûd, İrşâd, C: V, s. 734.

105 Ebussuûd, a.g.e., C: IV, s. 71.

106 Ebussuûd, a.g.e., C: V, s. 734.

107 es-Süyûtî, el-ìtkân, C: II, s. 734.

108 ez-Zürkānî, Menâhilü'l- 'irfân, s. 389.

109 Ebussuûd, a.g.e., C: II, s. 374.

110 Enfâl 8/64. 


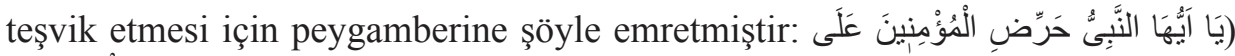

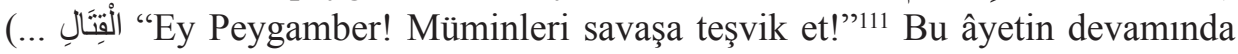
ise, kâfirlerin sayısı müminlerden on kat fazla da olsa müminlere yardım edece-

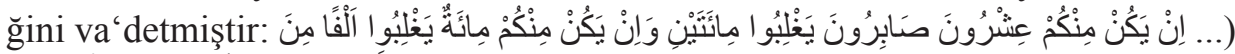
Eğer sizden sabirl1 yirmi kişi bulunursa inkâr edenlerden iki yüz kişiyi yener, sizden yüz kişi olursa, bin kişiyi yener; çünkü onlar yaptıklarının bilincinde olmayan bir topluluktur." 112

Ebussuûd Efendi'nin dediği gibi bu âyetin beyanıyla, savaş esnasında müminlerin düşmandan kaçmamaları ve kişi başına on kat fazla kâfire karşı sabır ve sebat etmeleri farz kılınmıştı. Bir müddet sonra bu durum Müslümanlara ağır

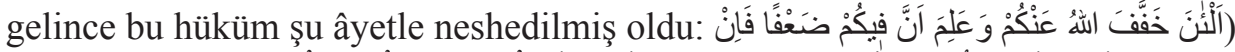

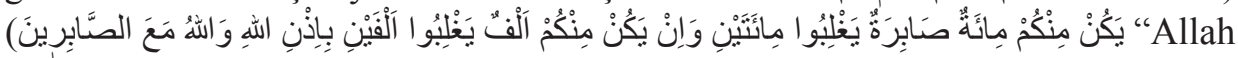
sizde bir zayıflık olduğunu bildi de şu andan itibaren yükünüzü hafifletti. Artık sizden sabırlı yüz kişi olursa Allah'ın izniyle iki yüz kişiyi yener, sizden bin kişi olursa iki bin kişiye yener. Allah sabredenlerle beraberdir." ${ }^{113}$ Böylece müminlere kolaylık sağlanmak suretiyle ancak kendilerinden iki kat fazla olan kâfirlere karşı direnmeleri farz k1lindi. ${ }^{114}$

\section{Kur'ân-ı Kerim'de Müşkil Âyetler Bulunmasının Hikmetleri}

Kur'ân-1 Kerim'de müşkil âyetler bulunmasının birtakım hikmetleri ve sebepleri vardır. Âlimler bunları tespit etmeye çalışmışlardır. Bunları genel olarak şöyle sıralayabiliriz:

Kur'ân-1 Kerim, Arapların kullandığı lafizlar ve ifade üsluplarıyla inmiştir. Zira îcâz, ihtisar, itnâb, tekit, işâret vs. onların kelâmının karakteristik özeliklerindendir. Bazen sadece iyi kavrayan anlasın diye mânayı üstü kapalı söylerler. Bazen de sözü açık zikrederler. Kimi zaman atasözü, kimi zaman deyim kullanırlar. İşte Kur'ân-1 Kerim de aynı üsluplarla gelmiştir. Şayet o Kitab'ın hepsi açık olsaydı, düşünmeye ihtiyaç duymadan âlim-câhil herkes tarafından hemen bilinseydi insanlar arasında fazilet farkı olmaz; meşakkat çekmenin değeri kalmaz; düşünceler körelirdi. Zira ihtiyacın ortaya çıkmasıyla birlikte fikir üretilir, çözümlere ve çarelere başvurulur. Yeterlik ve doygunluk duygusu ise âcizliğe ve düşünce donukluğuna sebep olur. ${ }^{115}$

111 Enfâl 8/65.

112 Enfâl 8/65. Bkz. Ebussuûd, İrşâd, C: II, s. 373-374.

113 Enfâl 8/66.

114 Ebussuûd, a.g.e., C: II, s. 374.

115 İbn Kuteybe, Te'vîlü müşkili'l-Kur'ân, s. 101. 
Âlimleri müşkil âyetler hakkında düşünmeye teşvik ederek, bunların çözümünü öğrenip diğer insanlara öğretmeye çalışmalarını sağlamaktır. Zira bu gibi âyetleri bilmek için gayret sarf etmek en büyük ibadetlerdendir. ${ }^{116}$

Müşkilin çözümünü araştıran ve buna katkıda bulunan kimselerin derecesinin üstünlüğü âşikâr olur. Âlim ile câhil birbirinden ayrilıp âlimin câhilden faziletli olduğu ortaya çıkmış olur. ${ }^{117}$

Müşkili anlamak, kastedilen manaya ulaşmak için çaba harcamayı gerektirir. Harcanan çaba ne kadar çok olursa kazanılan sevap da o kadar fazla olur. ${ }^{118}$

Müşkil âyetleri çözümlemek için te'lif ve tercih yollarını bilmeye ihtiyaç duyulur. Bu ise lügat, sarf, nahiv, meânî, beyân ve usûlü fikıh ilimlerini tahsil etmeyi gerektirir. Böylece müşkil âyetlerin Kur'ân'da zikredilmesi ile birçok faydalar hâs1l olur. ${ }^{119}$

Allah Teâlâ müşkil âyetlerle kullarını imtihan eder. Sadık haberlerine iman edip etmeyeni ortaya çıkarır. Zira Kur'ân'da şüphe eden, ettirmeye çalışan, onun âyetlerinde çelişki olduğunu iddia eden kimsenin mülhid olduğu insanlar nazarinda ortaya çıkar. ${ }^{120}$

Kur'ân-1 Kerim'in i'câz vasfinı ortaya koyar. Çünkü müşkilin araştırılıp halledilmesi Kur'ân'ın belâgat, nazım ve mana açısından mucizevî yönünü açığa çıkarır. ${ }^{121}$

Müslümanın mütevazı olmasını sağlar. Zira başkasının bildiği şeyleri bilmediğini görmek kişiyi ilim öğrenmeye ve acziyetini itiraf etmeye sevk eder. ${ }^{122}$

$\mathrm{Bu}$ âyetlerin arasını uzlaştırmak suretiyle şüphesiz inanca ve kalp huzuruna erilir. $^{123}$

\section{Âyetlerdeki Müşkili Gidermenin Önemi ve Hükmü}

Kur'ân-1 Kerim'in insanlara verdiği birçok mesajlar vardır. Bunların içerisinde müşkil olanlar da bulunmaktadır. Bunların manasını anlatmak âlimlere düşen bir görevdir. Âlimlerin bu görevlerini yerine getirmesiyle insanlar, Kur'ân-1 Kerim'in

116 es-Süyûtî, el-ïtkân, C: I, s. 668.

117 es-Süyûtî, a.g.e., C: I, s. 668.

118 es-Süyûtî, a.g.e., C: I, s. 669.

119 es-Süyûtî, a.g.e., C: I, s. 670.

120 Abdullah el-Mansûr, Müşkilü'l-Kur'âni'l-Kerîm, s. 77.

121 . ez-Zürkānî, Menâhilü'l-'irfân, s. 431.

122 Abdullah el-Mansûr, a.g.e., s. 77.

123 Ebussuûd, İşấd, C: I, s. 329. 
ifade ettiği irşad ve talimatları hakkıyla öğrenirler. Onun için Kur'ân-1 Kerim âyetlerindeki müşkili inceleyip tespit etmek ve bu işkâli ortadan kaldırmak önem arz etmektedir. Kitabullah'1 tefsir eden hiçbir müfessir Müşkilü'l-Kur'ân ilminden müstağni kalamaz. Çünkü bu ilim tefsir ilminin temellerinden birini teşkil eder. Onun için Ebussuûd Efendi demiştir ki: “Âyetlerdeki müşkilleri çözümlemek, anlaşılmayan yerlerini açıklamak, küllî hakikatlerini ortaya çıkarmak, anlayışların daraldığı, ayakların kaydığ 1 yerlerde Hakk'ın yollarını izah etmek, dalalet ehlinin şüphelerini iptal etmek için çaba sarfetmek en büyük ibadet ve taatlerdendir." 124

Bunun yanısıra Kur'ân-1 Kerim okuyan kimsenin zihnine bazen müsskil bir âyet takılabilir. Bu durumda o kimse bu müşkilin beyanına ihtiyaç duyar. Nitekim sahâbe-i kirâm kendilerine müşkil gelen âyetleri Peygamberimize sormuş ve açıklamasını ondan öğrenmişlerdir. Bundan da anlaşılmaktadır ki, Müslüman bir kimse Kur'ân âyetleriyle ilgili bir müşkille karşılaştığı zaman âlimlere danışarak veya onların eserlerini okuyarak o müşkilin çözüm yollarını aramalıdır. Nitekim

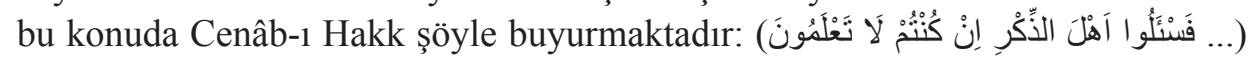
"Eğer bilmiyorsanız ilim sahiplerine sorun." 125

\section{Müşkilü'l-Kur’ân Hakkında Günümüze Kadar Yapılan Çalışmalar}

İslâm âlimleri ilk dönemlerden bu yana, âyetler arasında ilk bakışta teâruz izlenimi veren durumları tespit edip bunları çözümlemeye büyük önem göstermişlerdir. Bu tür âyetleri açıklamak için çeşitli eserler kaleme almışlardır. Kimisi müstakil olarak bu konuyu ele alırken kimisi de yazdıkları eserlerin bir bölümünde buna yer vermişlerdir. Âlimler yazmış oldukları müstakil eserlerde veya ilgili bölümlerde bu konuyu aynı başlık altında değil bilakis birbirine yakın farklı başlıklar altında zikretmişlerdir. "Müşkilü'l-Kur'ân", "Müşkilü'l-Kur'ân ve mûhimü'l-ihtilâf ve't-tenâkuz", "Mûhimü'l-ihtilâf", "Mâ evheme't-tenâkuz ve't-teâruz ve leyse bi-mütenâkız ve la bi-müteârız" ve "Def"u ızdırâb 'an âyi'lKitâb" bu başlıklardan bazılarıdır. Saydığımız bu başlıkların hepsi, "bazı ayetler arasında var olduğu zannedilen ihtilaflı durumları inceleyen ve bunları çözüme kavuşturan ilim" anlamını ifade etmektedir.

Müşkilü’l-Kur'ân'a dair yapılan çalışmaları üç sınıfta değerlendirmemiz mümkündür. Bunlardan ilki, sadece müşkil âyetlere yer veren müstakil eserlerdir. İkincisi, Müsskilü'l-Kur'ân'1 bir bölüm olarak ele alan bazı 'ulûmü'l-Kur'ân ve tefsir usûlü eserleridir. Üçüncüsü, yeri geldikçe müşkil âyetleri açıklayan tefsir kitaplarıdır.

124 Ebussuûd, a.g.e., C: IV, s. 479.

125 Nahl 16/43; Enbiyâ 21/7. 
Müşkilü'l-Kur'ân konusuyla ilgili yapılan çalışmalarda konuyla ilgili çalışmaların listesi verilmiştir. Fakat bu listeler genelde karmadır. Yani Kur'ân'daki i'râb müşkilleri, garîb ve müşkil kelimeler, fikıh ihtilaflarıyla ilgili müşkiller, aralarında ihtilaf olduğu sanılan âyetler konusuna dair yazılan eserlerin hepsi müşkilü'l-Kur'ân başlığı altında listelenmiştir. Oysa müşkilü garîbi'l-Kur'ân, müşkilü i'râbi'l-Kur'ân, Kur'ân'daki müşkil fikıh konuları ve çelişkili olduğu sanılan âyetler alanında yazılan müşkil eserlerin ayrı kategoride sıralanması araştırıcılara kolaylık sağlaması açısından önemlidir. Gördüğümüz kadarıyla bu listelerde buna temas edilmemiştir. Mesela sadece müşkilü'l-Kur'ân konusunu ele alan ve i'râbla ilgili müşkillerden bahsetmeyen çalışmalarda verilen listelerde i'râb müşkilleri ve garîbü müşkili'l-Kur'ân'a dair yazılan eserler de sıralanmıştır. ${ }^{126}$ Biz ise aşağıda verdiğimiz listede, sadece çelişkili zannedilen âyetlere dair ulaşabildiğimiz eserlere yer verdik.

II. (VIII.) Yüzyılın Başlarından Günümüze Kadar Müşkilü'l-Kur'ân Konusundaki Çalışmaların Kronolojik Listesi ${ }^{127}$

\section{II. (VIII.) Yüzyıl}

Mukâtil b. Süleymân (v. 150/767), Tefsîrü'l-hamsi mi'e âye mine'l-Kur'ân, nşr. Isaiah Goldfeld, Şefâ Amr [Filistin], 1980. Aralarında ihtilaf zannedilen dokuz konunun zikredildiği İbn Abbas (ra)'dan gelen rivâyete yer verilir. s. 281-283.

Süfyân b. Uyeyne (v. 198/814), Cevâbâtü'l-Kur'ân. Bu eser kaynaklarda zikredilmekle birlikte ${ }^{128}$ yaptığımız araştırmada esere ulaşamadık.

\section{III. (IX.) Yüzyll}

Ebû Ali Muhammed b. el-Müstenîr Kutrub (v. 206/821), er-Red 'ale'l-mülhidîn fî müteşâbihi'l-Kur'ân. Kaynaklar bu eserden bahsetmekle birlikte ${ }^{129}$ eserin varlığından haberdar olamadık. Süyûtî, ihtilaflı gibi görünen âyetler konusunda Kutrub'un müstakil bir eser telif ettiğini belirtir fakat eserin ismi-

126 Mesela bkz. Abdülmuhsin b. Zeben el-Mutayrî, De 'âva 't-tâinîn fi'l-Kur'âni'l-Kerîm fi'l-karni'r-râbi ‘i 'âşere'l-hicrî ve'r-red 'aleyhâ, Beyrut, Dârü'l-beşâiri'l-İslâmiyye, 1427/2006, s. 58-69.

127 Bu listede, "zâhirde ihtilaflı gibi görünen" müşkil âyetleri müstakil veya kısmî olarak ele alan çalışmaları zikrettik. Bunlardan matbu olanların basım yerlerini, mahtut olanların bulunduğu kütüphaneleri, mefkûd olanların ise bibliyografi kitaplarındaki yerlerini tespit etmeye çalıştık.

128 Ebû'l-Ferec Muhammed b. Ebî Ya'kûb el-Verrâk en-Nedîm (v. 385/995[?]), el-Fihrist, nşr. Rızâ Teceddüd, Tahran, 1391/1971, s. 37.

129 en-Nedîm, a.g.e., s. 58. 
ni zikretmez. Onun belirttiği eserin bu eser olması kuvvetle muhtemeldir. Zira Kutrub'un müşkille ilgili olan Me 'ani'l-Kur'ân ve tefsîrü müsskili 'irâbih' ${ }^{130}$ adlı diğer eserini incelediğimizde, i'râbla ilgili müşkil konular başta olmak üzere lügat, garîbü'l-Kur'ân ve kıraatle ilgili konuları ihtivâ ettiğini gördük. Dolay1syyla Murat Sülün'ün, Süyûtî'nin belirttiği eserin $M e$ 'ani'l-Kur'ân olduğunu söylemesi isabetli görünmemektedir. ${ }^{131}$ Nitekim Abdülmuhsin el-Mutayrî de, Süyûtî'nin zikrettiği bu eserin yukarıda zikredilen er-Red 'ale'l-mülhidîn fî müteşâbbihi 'l-Kur' ân olduğunu söylemiştir. ${ }^{132}$ Zerkeşî de bu eseri gördügünü ve güzel bulduğunu söyler. ${ }^{133}$

Ahmed b. Hanbel (v. 241/855), er-Red 'ale'z-Zenâdıka ve'l-Cehmiyye fìmâ şekket fihi min müteşâbihi'l-Kur'ân ve teevvelethü 'alâ gayri te'vîlih, nşr. Dagiş b. Şebîb el-'Acmî, Kuveyt, Garas li’n-neşr ve’t-tevzi, 1426/2005. İbn Hanbel, bu eserin "Beyânü mâ dallet bihi'z-zenâdıka min müteşâbihi'l-Kur'ân” başlığında yirmi iki meselenin açılamasına yer vermiştir. ${ }^{134}$ Görüldüğü gibi İbn Hanbel, müşkil tabiri yerine müteşâbih ifadesini kullanmıştır. Buna göre, müşkil ve müteşâbih kavramlarının o dönem eş anlamda (müterâdif) kullanıldığı anlaşılmaktadır. Nitekim aynı dönem müelliflerinden İbn Kuteybe'nin de bu kelimeleri eşanlamda kullandığından bahsetmiştik.

İbn Kuteybe (v. 276/889), Te 'vîlü müşkili'l-Kur'ân, nşr. Sa‘d b. Necdet Ömer, Beyrut, Müessesetü'r-risâle nâşirûn, 1435/2014, s. 83-99; nşr. es-Seyyid Ahmed Sakr, Kahire, Mektebetü dâri't-türâs, 1427/2006. Alanında meşhur bir eserdir. İbn Kuteybe, âyetlerinde çelişki var diyerek Kur'ân-1 Kerîm'e saldırıda bulunan mülhidlerin batıl iddialarına cevap vermek amacıyla kaleme aldığı bu eserinde "Bâbu't-tenâkuz" ismiyle bir başlık açmış ve onlara cevaplar vermiştir. ${ }^{135}$

Mufaddal b. Seleme (v. 290/903'ten sonra), Ziyâü'l-kulûb fì me 'ani'l-Kur'ân ve garîbihî ve müşkilih. Bu eser kaynaklarda zikredilmekle birlikte ${ }^{136}$ günümüze kadar ulaşıp ulaşmadığı bilinmemektedir.

130 Bir nüshası Cezâir'in Tolga şehrinde nadir yazmalar barındıran Osmâniye Kütüphanesi'ndedir. Bu nüshanın yedinci cüzünün başlığında eser bu isimle kaydedilmiştir. Eserin yazması için bkz. http://www.mediafire.com/file/daaije6sd2ap2aa/kotrop.rar

131 Murat Sülün, “Mahiyeti, Sebep ve Çözümleri Çerçevesinde Müşkilü’l-Kur'ân”, Kur'ân ve Tefsir Araştırmalart-III, İstanbul 2002, s. 331.

132 el-Mutayrî, De 'âva 't-tâinîn, s. 47.

133 ez-Zerkeşî, el-Burhân, C: II, s. 45.

134 Ahmed b. Hanbel, er-Red 'ale'z-Zenâdıka ve'l-Cehmiyye, s. 75-196.

135 İbn Kuteybe, Te 'vîlü müşkili'l-Kur'ân, s. 116-131.

136 en-Nedîm, a.g.e., s. 37. 


\section{IV. (X.) Yüzyıl}

İbnü'l-Haddâd Saîd b. Muhammed el-Gassânî (v. 302/915), Tavzîhu'l-müşkil fi'l-Kur'ân. ${ }^{137}$ Eserin yazmasina ait bir bölüm Kayrevan Ulucamii'nde bulunmaktadır. ${ }^{138}$

Ebû Bekr Muhammed b. el-Kâsım el-Enbârî (v. 328/940), Müşkilü'l-Kur'ân. Kaynaklarda adından bahsedilmekle birlikte ${ }^{139}$ varlığı hakkında şimdilik bir bilgiye sahip değiliz.

Malatî, Ebu'l-Hüseyin (v. 377/987) et-Tenbîh ve'r-red 'alâ ehli'l-ehvâ ve'l-bida', nşr. Sven Dedering, İstanbul, Matbaatü'd-devle 1936; nşr. M. Zâhid el-Kevserî, Kahire 1993.

Ebû Halef Abdülaziz es-Saydelânî el-Merzubânî, el-Muvazzah fî me 'âni'l-Kur' ân ve keşfü müşkilâti'l-Furkân, Süleymaniye Ktp., Ayasofya, nr. 297/2, 244 varak.

İbn Fûrek (v. 406/1015), Müşkilü'l-Kur'ân. İbnü'l-Vahşî Abdullah b. Yahyâ et-Tücîbî el-Uklîşî tarafından ihtisar edilmiştir. ${ }^{140}$

İbnü'l-Cerrâh, Ebü'l-Hasan Ali b. Îsâ (v. 334/946), Me 'ani'l-Kur'ân ve tefsîruhû ve müşkilüh Kaynaklarda adı geçmekle beraber ${ }^{141}$ mevcudiyeti hakkında şimdilik bir bilgimiz yoktur.

\section{V. (XI.) Yüzyıl}

Kâdî Abdülcebbâr (v. 415/1025), Tenzîhü'l-Kur'ân 'ani'l-metâin, nşr. Hidr Muhammed Nebhâ, Beyrut, Dârü'l-kütübi'l-'ilmiyye, 2008. Müellif, isminden de anlaşılacağı üzere bu eserde Kur'ân-1 Kerim'e yöneltilebilecek tenkitlere cevap vermiştir. Yaklaşık 846 soruya yer verilmiştir. İki âyet arasında tenâkuz gibi görünen meseleler de çözümlenmiştir. Müellif itikatla ilgili âyetleri müntesibi olduğu Mu'tezile mezhebine göre yorumlamıştır. ${ }^{142}$

137 Ebü'l-Hasen Cemâlüddîn Alî b. Yûsuf el-Kıftî (v. 646/1248), İnbâhu'r-ruvât 'alâ enbâhi'n-nuhât, 4 c., nşr. Muhammed Ebu'l-Fadl İbrahim, Kahire, Daru'l-Fikri'l-Arabî, 1406/1986, C. II, s. 53; Ebû Gays Muhammed Hayrüddîn b. Mahmûd ez-Ziriklî (1893-1976), el-A'lâm Kamûsü terâcim li-eşheri'r-ricâl ve'n-nisâ min'el- 'arab ve'l-müsta 'rebîn ve'l-müsteşrikîn, 8 c., 15. bs., Beyrut, Dâru'l-'ilmi li'l-melâyîn, 2002, C. III, s. 100.

138 ez-Ziriklî, a.g.e., C. III, s. 100.

139 Ebû Abdillâh Şemsüddîn Muhammed b. Ahmed b. Osmân ez-Zehebî (ö. 748/1374), Siyeru a 'lâmi'n-nübelâ, 25 c., Beyrut, Müessesetü'r-risâle, 1996. 1405/1985, C: XV/276, 512.

140 Bkz. Yâkût el-Hamevî, Ebû Abdillah Şihâbüddîn Yâkût b. Abdillâh (v. 626/1229), Mu'cemü'l-büldân, 5 c., Beyrut, Dârü ihyâi't-türâsi'l-Arabî, 1399/1979, C: I, s. 237.

141 Bkz. en-Nedîm, el-Fihrist, s. 37.

142 Kâdî Abdülcebbâr, Tenzîhü'l-Kur'ân 'ani 'l-metâ 'in, nâşirin mukaddimesi s. 6-7 ve 10. 
Ebû Abdillâh Muhammed b. Abdillâh el-Hatîb el-İskâfî (v. 420/1029), Dürretü 't-tenzîl ve gurretü 't-te'vîl fì beyâni 'l-âyâti'l-müteşâbihât fí Kitâbi'llâhi'l- 'Azîz, Beyrut, Dârü'l-kütübi'l-'ilmiyye, 1433/2012. Eser ağırlıklı olarak lafızca birbirine benzeyen âyetlerin açıklamasına dairdir. İskâfî, bu eserinde zahirde ihtilaflı gibi görünen âyetlerin çözümüne de nadir olarak yer verir. Mesela İblîs'in bazı âyetlerde Allah'1n saptırmasına yemin etmesini ${ }^{143}$, bazısında ise Allah'ın izzetine yemin etmesini ${ }^{144}$ birbiriyle uzlaştırma (te'lif) yoluyla çözmüştür. ${ }^{145}$

eş-Şerîf el-Murtazâ, Ebü'l-Kâsım Alî b. el-Hüseyn (v. 436/1044), Emâli'l-Murtazâ/Gurerü'l-fevâid ve dürerü'l-kalâid (Emâlî), thk. Muhammed Ebü'lfazl İbrâhîm, Beyrut, el-Mektebetü'l-'asriyye, 1425/2004.

Şeyzele Ebü'l-Me‘âlî Azîzî b. Abdülmelik el-Cîlî (v. 494/1100), el-Burhân fì müşkilâti'l-Kur'ân. Süyûtî bu eseri gözden geçirdiğini ve el-İtkân'ın kaynakları arasında olduğunu zikreder. ${ }^{146}$ Günümüze kadar ulaşıp ulaşmadığ 1 bilinmemektedir.

İbn Mutarrif el-Kinânî (v. 454/1062), el-Kurtayn. İbn Mutarrif, İbn Kuteybe'nin Müşkilü'l-Kur'ân'1 ile Garîbü'l-Kur'ân'1nı Mushaf tertibine göre düzenleyip birleştirerek el-Kurtayn adıyla yeni bir eser meydana getirmiştir. Beyrut, Darü'l-ma'rife, ts.

\section{VI. (XII.) Yüzyıl}

Ebü'l-Kâsım Tâcülkurrâ Burhânüddîn Mahmûd b. Hamza el-Kirmânî (v. 500/1106'dan sonra) el-Burhân fì tevcihi müteşâbihi'l-Kur'ân limâ fỉhi mine'l-hücce ve'l-beyân (Esrâru't-tekrâr fi'l-Kur'ân), nşr. Abdülkâdir Ahmed Atâ, Kahire, Dârü'l-fazîlet, 1978. Tekrar edilen âyetlerin yoğun olarak ele alındığ 1 eserde tekrarın sebepleri, takdim, tehir, ziyade, ibdal gibi konular açıklanmaktadır. Âyetler arasındaki zâhirî teâruz ve ihtilaf konusuna nadir yer verilir.

en-Nîsâbûrî, Ebu'l-Kâsım Mahmud b. Ebü'l-Hasen Ali (v. 553/1158'den sonra), Dürerü'l-kelimât 'alâ gureri'l-âyâti'l-mûhimeti li 't-te' âruz ve'ş-şübühât. ${ }^{147}$ Günümüze kadar ulaşıp ulaşmadığ 1 bilinmemektedir.

143 A'râf 7/16; Hicr 15/39.

144 Sâd 38/82.

145 el-İskâfî, Dürretü 't-tenzîl, s. 78-79.

146 Süyûtî, el-ìtkân, C: I, s. 20.

147 Bağdatlı İsmail Paşa (1839-1920), İzâü'l-meknûn fi'z-zeyl 'alâ Keşfi'z-zunûn 'an esâmi'lkütüb ve'l-fünûn, nşr. Şerefeddin Yaltkaya-Kilisli Rifat Bilge, 2 c., Milli Eğitim Basımevi 1945-47 İstanbul, (Beyrut, Dârü ihyâi't-türâsi'l-Arabî ofset, 1405/1985), C: I, s. 468. 
, Bâhirü’l-burhân fì müşkilâti me 'âni'l-Kur'ân, nşr. Suâd bint Sâlih b. Saîd Bâbekî, 2 c., Mekketü'l-mükerreme, Ümmü'l-kurâ üniversitesi bs., 1419/ 1998. Diğer adıyla Vazahu'l-burhân fî müşkilâti'l-Kur'ân, nşr. Safvân Adnân Dâvûdî, 2 c., Dımaşk, Dârü'l-kalem, 1410/ 1990. Bazı kitaplarda bu iki eser Nîsâbûrî’nin iki ayrı eseriymiş gibi gösterilmiştir. ${ }^{148}$ Bunları karşılaştırdığımızda ikisinin de aynı eser olduğu kanaatine vardık. ${ }^{149}$ Bâhirü'l-burhân, âyetlerde geçen garîb kelimeleri izah eder. Âyetler arasındaki irtibatı açıklar. Âyetlerin birbiriyle olan münasebetine, lafizca birbirine benzeyen âyetlerdeki tekrarın hikmetlerine ve müşkil sayılacak birçok konuya yer verir. Bununla birlikte eser, nadir olarak müteârız gibi görünen âyetlerin çözümüne de değinir.

\section{VII. (XIII.) Yüzyıl}

İzzeddîn Abdülazîz b. Abdüsselâm (v. 660/1262), Fevâid fì müşkili'l-Kur'ân, nşr. Seyyid Ridvân Ali Nedvî, Cidde, Dâru'ş-şurûk, 1402/1982, 326 sayfa. Âyetlerde geçen anlaşılması zor kelimelerin açıklamasına yer verildiği gibi teâruz görünümündeki âyetleri de açıklamaktadır.

er-Râzî, Ebû Abdillah Zeynüddin Muhammed b. Ebî Bekir (v. 666/1268), Es'iletü'l-Kur'âni'l-mecîd ve ecvibetühâ, Beyrut, el-Mektebetü'l-'asriyye, 1431/2010. 1236 mesele soru-cevap tarzında ele alınmıştır. İhtilaflı gibi görünen âyetler arasındaki müşkillerin çözümüne de yer verilmiştir. Râzî’nin Müşkilâtü'l-Kur'ân ismiyle zikredilen eseri de muhtemelen aynı eser olmalıdır. Yazması için bkz. Ezher Ktp. (425 Tefsir ve ulûmü'l-Kur'ân) nr. 259/32928.

Sadreddîn Konevî (v. 673/1274), Şerhu me 'ânî müşkilâti'l-Kur'ân, Süleymaniye Ktp. Pertev Paşa 647, $78^{\mathrm{b}}-131^{\mathrm{b}}$ vr.

\section{VIII. (XIV.) Yüzyıl}

Ahmed b. İbrahim İbnü'z-Zübeyr es-Sekafî (v. 708/1308 ), Milâkü̈t-te'vîli'l-kâtı' bi-zevi'l-ilhâd ve't-ta'tîl fì tevcîhi'l-müteşâbihi'l-lafz min âyi't-tenzîl (Basılmış doktora tezi), 2 c., 5. bs., nşr. Saîd el-Fellâh, Tunus, Dârü'l-garbi'l-İslâmî, 2013. Eser, müellifin mukaddimede belirttiği üzere birtakım ilavelerle İskâfî'nin Dürretü 't-Tenzîl ve gurretü 't-te'vîl' i üzerine bina edilmiştir. Çoğunlukla âyetlerdeki lafzî benzerliklerin sebepleri ve hikmetleri üzerinde durulur. Az da olsa ihtilaflı gibi görünen âyetlerin çözümüne yer verilir. ${ }^{150}$

148 Bkz. el-Mutayrî, De 'âva 't-tâinîn, s. 59-60.

149 Suâd Bâbekî de ikisinin aynı eser olduğunu söyler. Ayrıca kitabın orijinal isminin Bâhirü'l-burhân fì müşkilâti me 'âni'l-Kur'ân olmasının kuvvetle muhtemel olduğunu delilleriyle ispatlamaya çalışır. Bkz. Bâhirü'l-burhân (Dirâset kısmı), C: I, s. 302.

150 Mesela bkz. C. I, s. 532-533. 
Kutbüddîn Mahmûd b. Mes'ûd Şîrâzî (v. 710/1311), Müşkilâtü 't-tefâsîr, Süleymaniye Ktp., Yenicami, nr. 9/149. ${ }^{151}$

Takıyyüddîn İbn Teymiyye (v. 728/1328), Tefsîru âyâtin eşkelet 'âlâ kesîrin mine'l- 'ulemâ hattâ lâ yûced fî tâifetin min kütübi 't-tefsîr fîhâ el-kavlü 'ssavâb bel lâ yûced fîhâ illâ mâ hüve hata', 2 c., nşr. Abdülazîz b. Muhammed el-Halîfe, Riyad, Mektebetü'r-rüşd, 1996. Kitapta daha çok anlaş1lması zor olan âyetler incelenir. Zâhirde ihtilaflı görünen ayetlere çok nadir yer verilir.

Şerefüddin, Hüseyin b. Süleyman b. Reyyân (v. 770/1368-69), er-Ravzu'r-reyyân fì es'ileti'l-Kur'ân, 2 c., nşr. Abdülhalim b. Muhammed Nassâr es-Selefî, el-Medinetü'l-münevvere, Mektebetü'l-'ulûm ve'l-hikem, 1415/1994. Soru-cevap tarzında kaleme alınan eserde, birbiriyle mütenâkız gibi görünen âyetlerin çözümüne de yer verilmektedir.

Cemaleddîn Aksarâyî (v. 791/1389), Şerhu müşkilâti'l-Kur'âni'l-Kerîm ve şerhu müşkilâti'l-ehâdîsi rasûli Rabbi'l- 'âlemîn. Daha çok Kitabü'l-es 'ile ve'l-ecvibe adıyla bilinmektedir. Eserin II. Bayezid'e takdim edilen sultânî nüshası için bkz. Süleymaniye Ktp., Ayasofya, nr. 71. Zâhirde ihtilaflı görünen ayetleri ve hadisleri te'lif ve te'vil etmeyi soru ve cevap tarzında ele alan eser, müteşâbih ve mücmel ifadelere de yeri geldikçe değinir. Dili Farsça'dır. ${ }^{152}$

\section{X. (XVI.) Yüzyıl}

Ebû Yahyâ Zeynüddîn Zekeriyyâ b. Muhammed es-Süneykî (v. 926/1520), Fethu'r-Rahmân bi-keş̧i mâ yeltebisü fi'l-Kur'ân, nşr. Muhammed Ali es-Sâbûnî, Beyrut, Âlemü'l-kütüb, 1405/1985. Lafızca birbirine benzeyen âyetleri açıklayan eser, çelişkili gibi görünen âyetleri de çözümler.

Ebû Abdullah Muhammed b. Ali eş-Şatîbî (v. 963/1556), el-Envâr fî müşkilâti âyâtin mine'l-Kur'ân. , el-Lübâb fì müşkilâti'l-Kitâb. ${ }^{153}$

\section{XII. (XVIII.) Yüzyıl}

Muhammed Emîn b. Hayrullah el-Hatîb el-Ömerî (v. 1203/1789), Tîcânü'l-beyân fî müşkilâti'l-Kur'ân, nşr. Hasan Muzaffer er-Rezzû, Bağdat, Matba-

151 el-Fihrisü'ş-şâmil li't-türâsi'l-Arabiyyi'l-İslâmiyyi'l-mahtût: 'Ulûmü'l-Kurân, mahtûtâtü 't-tefsir ve 'ulûmih, nşr. el-Mecmeu'l-melikî libuhûsi'l-hadâreti'l-İslâmiyye, Müessesetü Âli'l-beyt, Amman 1989, I, 353.

152 Geniş bilgi için bkz. Necattin Hanay, “Aksarâyî’nin Kitabü'l-Es'ile ve'l-Ecvibe'si ve Yorum

Metodu”, Dinbilimleri Akademik Araştırma Dergisi, C: XVII, sy. 2, (2017), s. 171-198.

153 Her iki eserin yazmaları için bkz. el-Fihrisü'ş-şâmil, I, 604. 
atü İşbîliyyeti'l-hadîse, 1404 h. Müellif bu eserinde çelişkili zannedilen müşkil âyetleri toplamış ve bunları sade bir üslupla çözümlemiştir. Ayrıca bunların çözümünde âlimlerin görüşlerinden de sıkça yararlanmıştır.

Muhammed Hayât es-Sindî (v. 1163/17), Risâle fi'r-red 'âlâ men idde 'a 'ttenâkuz fî kelâmillâh. ${ }^{154}$

Ebû İbrâhîm İzzüddîn Muhammed b. İsmâîl es-San'ânî (v. 1182/1768), Ref'u işkâli'l-âyâti'l-kâzlye ba 'zuhâ bi takdîmi halkı 's-semâvat. Yerler ve göklerin hangisinin daha önce yaratıldığına dair müşkili inceleyen ve buna dair âyetleri konu edinen bir risaledir. ${ }^{155}$

\section{XIII. (XIX.) Yüzyıl}

Ahmed b. Süleyman el-Ahmedî el-Kâdirî el-Hâlidî (v. 1270/1856), el-Kavlü'l-müfíd fî halli ba 'zı müskilâtin mine'l-Kur'âni'l-mecîd. ${ }^{156}$

\section{XIV. (XX.) Yüzyıl}

Muhammed Abduh (v. 1905), Müskilâtü'l-Kur'âni'l-Kerîm ve tefsîrü sûreti'l-Fâtiha, Kâhire 1323 h.; Beyrut, Dârü mektebeti'l-hayât, ts. Tefsir ilimine dair bir mukaddime, üç makale ve Fâtiha sûresinin tefsirinden oluşan eser Abduh'un talebesi M. Reşîd Rızâ tarafından derlenmiştir. Üç makaleden birincisi, iki âyet arasında var olduğu sanılan ihtilafı çözümlemektedir. İlk âyet, iyiliğin de kötülügün de Allah katından olduğunu ifade etmektedir. ${ }^{157}$ İkincisi ise, iyiliğin Allah katından kötülüğün ise nefisten olduğunu ifade eden âyettir. ${ }^{158}$

Muhammed Enver el-Keşmîrî (v. 1933), Müşkilâtü'l-Kur'ân, Delhi 1938; Mültan, ts. (İdâre-i Te'lîfât-1 Eşrefiyye). Kırk sekiz sûrede yer alan 190 müşkil âyetin açılandığı eser Muhammed Yûsuf Bennûrî tarafından neşredilmiş ve baş tarafına nâşirin Yetîmetü'l-beyân li-müşkilâti'l-Kur'ân adındaki risâlesi eklenerek basılmıştır.

Muhammed Emîn eş-Şinkîtî (v. 1974), Def'u îhâmi'l-lzdırâb 'an âyâti'lKitâb, el-Mekketü'l-mükerreme, Daru 'âlemi'l-fevâid, 1426 h. Aralarında ihtilaf var sanılan birbirinden farklı konularda 219 mesele çözümlenmektedir.

154 el-Fihrisü'ş-şâmil, II, 763.

155 el-Fihrisü'ş-şâmil, II, 774.

156 Salâh el-Haymî, Fihrisü mahtûtâti dâri'l-kütübi'z-zâhiriyye: 'Ulûmü'l-Kurâni'l-Kerîm, D1maşk, Matbûâtü mecmai'l-lügati'l-Arabiyye, 1403 h., C: II, s. 242.

157 Nisâ 4/78.

158 Nisâ 4/79. Müşkilâtü'l-Kur'âni'l-Kerîm, s. 68-74. 


\section{XV. (XXI.) Yüzyıl}

Halîl Yâsîn (v. 1405/1984), Edvâün 'alâ müteşâbihâti'l-Kur'an, 2 c., Beyrut, Dâru ve mektebetü'l-hilâl, 1969. Kitabın müellifi imâmiyye şiasındandır. 1651 soru cevabı ihtiva eden eser, lafizca birbirine benzeyen âyetleri ele aldığ 1 gibi aralarında teâruz izlenimi olan âyetleri de açıklar.

İmâd Tâhâ Ahmed Râ‘ûş, "Mûhimü’t-tenâkuz fi'l-Kur'âni'l-Kerîm: Dirâsetün nazariyye ve nemâzicü tatbîkıyye”, Mecelletü'l- 'ulûmi'ş-şer 'iyye, sy. 27, Kasîm, Camiatü'l-Kasîm, 1424/2003, s. 467-528.

Abdullah b. Hamed el-Mansûr, Müşkilü'l-Kur'âni'l-Kerîm (basılmış yüksek lisans tezi), el-Memleketü'l-Arabiyyetü's-Su'ûdiyye, Dâr'ü-bni'l-Cevzî, $1426 \mathrm{~h}$.

Abdülmuhsin b. Zeben el-Mutayrî, De 'âva 't-tâinîn fi'l-Kur'âni'l-Kerîm fi'lkarni'r-râbi ‘i 'âşere'l-hicrî ve'r-reddü 'aleyhâ (basılmış doktora tezi), Beyrut, Dârü'l-beşâiri'l-İslâmiyye, 1427/2006.

Yâsir b. Ahmed eș-Şimâlî, Mûhimü'l-ihtilâf ve 't-tenâkuz fi'l-Kur 'âni'l-Kerîm (basılmamış yüksek lisans tezi), el-Mekketü'l-mükerreme, Camiatü Ümmi'lkurâ, 1427 h.

Abdurrahman b. Sâlih el-Muhaymîd, Mûhimü 't-te 'âruz beyne'l-Kur'ân ve's-sünne: Dirâsetün nazariyye ve tatbîkıyye min evveli sûreti'l-Fâtiha hattâ nihâyeti sûreti'l-En 'âm (basılmamış yüksek lisans tezi), Riyad, Camiatü Ümmi'lkurâ, 1427 h.

Âyiş Ali Muhammed Lubâbine, "Dirâse fî̀ Müşkili'l-Kur'ân, Te’vîlü kavlihî Teâlâ: Ve erselnâhü ilâ mieti elf ev yezîdûn", el-Mecelletü'l-Ürdüniyye fí'd-dirâsâti'l-İslâmiyye, C: V, sy. 3/A, 1430/2009, s. 71-87.

Hâlid b. Abdullah b. Ömer ed-Demîcî, Def'u îhâmi 't-te 'âruz 'ani' l-âyâti'l-vâride fi'l-îmân bi'r-rusül ve'l-kader (basılmamış doktora tezi), el-Mekketü'l-mükerreme, Camiatü Ümmi'l-kurâ, 1427 h.

Muhammed Ebü'n-Nûr el-Hadîdî (v. 2008), el-Beyân fí def'i 't-te 'âruzi'l-mütevehhem beyne âyâti 'l-Kur'ân, Kahire, Matbaatü'l-emâne, 1401/1981. Müellif, aralarında teâruz var olduğu zannedilen âyetlere dair 89 meseleyi inceler.

\section{Müşkilü'l-Kur'ân Bölümüne Yer Veren Bazı Ulûmü'l-Kur'ân Eserleri}

ez-Zerkeşî, Ebû Abdillâh Bedrüddîn Muhammed b. Bahâdır (v. 794/1392), el-Burhân fì 'ulûmi'l-Kur' ân, nşr. Muhammed Ebü'l-Fazl İbrâhîm, 4 c., Kâhire, Dârü't-türâs, 1376/1957. 
es-Süyûtî, Ebü'l-Fazl Celâlüddîn Abdurrahmân b. Ebî Bekr (v. 911/1505), el-ìtkân fì 'ulûmi'l-Kur'ân, nşr. Mustafa Dîb el-Bugâ, 2 c., Beyrut, Dâr'ü-bni Kesîr, 1416/1996.

İbn Akîle, Cemâlüddîn Ebû Abdillah Muhammed b. Ahmed el-Mekkî (v. 1150/1737), ez-Ziyâde ve'l-ihsân fì 'ulûmi'l-Kur'ân, nşr. Muhammed Safâ Hakkî (nev' 1-45), Fehd b. Ali el-Ândes (nev' 46-90), İbrâhîm b. Muhammed el-Mahmûd (nev' 91-119), Muslih b. Abdülkerîm es-Sâmidî (nev‘ 120-143), Hâlid Abdülkerîm el-Lâhim (nev`144-154), 10 c., el-'İmârâtü'l-Arabiyyetü'l-müttahide, Merkezü'l-buhûs ve'd-dirâsât-Câmi 'atü'ş-şârika, 1427/2006.

Fazl Hasan Abbâs (v. 2011), İtkânü'l-Burhân fî 'ulûmi 'l-Kur'ân, 2 c., I. C. Amman, Darü'l-furkân, 1997; II. C. Amman, Dârü'n-nefâis, 1430/2010.

\section{Ülkemizde Müşkilü'l-Kur'ân'a Dair Yapılan Bazı Bilimsel Çalışmalar}

İsmail Cerrahoğlu, Tefsir Usûlü, 12. bs., Türkiye Diyanet Vakfi Yayınları, Ankara 1997. Eserde müşkilü'l-Kur'ân konusu ayrı bir bölüm olarak işlenir. İlk baskısı 1971 yılında Ankara Üniversitesi İlahiyat Fakültesi tarafından yapılmıştır.

Yakup Çiçek, “Müşkilü’l-Kur'an”, Marmara Üniversitesi İlahiyat Fakültesi Dergisi, sy. 7-8-9-10, İstanbul 1989-1992, s. 79-112.

Osman Şahin, Kur'ân-ı Kerim'deki Müsskil Iffadeler ve Çözüm Yolları (bası1mamış yüksek lisans tezi), Samsun, Ondokuz Mayıs Üniversitesi Sosyal Bilimler Enstitüsü, 1996.

Müjdat Uluçam, Kur' an Âyetleri ve Hadisler Arasında Görülen Teâruz ve Çözüm Yolları (basılmamış doktora tezi), İstanbul, Marmara Ünv. Sosyal Bilimler Enstitüsü, 1997.

Süleyman Pak, Müşkilü'l-Kur'ân (basılmamış doktora tezi), Konya, Selçuk Ünv. Sosyal Bilimler Enstitüsü, 2000.

, "Ayetlerde Çelişki Bulunduğu Vehmini Gidermede Kullanılan Yöntemler ve Bunların Değerlendirilmesi”, Sosyal Bilimler Araştırmaları Dergisi-II, 2013, s. 112-128.

Muhsin Demirci, Tefsir Usûlü ve Tarihi, 2. bs., İstanbul, Marmara Ünv. İlahiyat Fakültesi Vakfı Yayınları, 2001. Eserde müsskilü'l-Kur'ân konusuna ayrı bir bölümde yer verilir.

Muhammed Aydın, "Kur'ân Ayetlerinde Çelişki Görünümü Veren Sebepler ve Giderilmesi”, Sakarya Üniversitesi Illahiyat Fakültesi Dergisi, sy. 3, 2001, s. 119-136.

Murat Sülün, "Mahiyeti, Sebep ve Çözümleri Çerçevesinde Müşkilü'l-Kur'ân”, Kur'ân ve Tefsir Araştırmalart-III, İstanbul 2002, s. 329-346. 
Âdem Yerinde, "İlk Bakışta Çelişki Görünümü Veren Müşkil Âyetler ve Etrafinda Oluşan Bilimsel Edebiyat”, Sakarya Üniversitesi İlahiyat Fakültesi Dergisi, sy. 16, 2007, s. 29-61.

Abdülcelil Candan, Kur 'ân Okurken Zihne Takılan Âyetler-Müşkilü'l-Kur'ân, 2. bs., İstanbul, Elest Yayınları, 2007.

, Ulemayı Uzun Süre Düşündüren Anlaşılması Güç Âyetlerin Tefsiri: Müskilü'l-Kur'ân, Konya, Kitap Dünyası, 2001.

Ahmet Özbay, Kurtubî Tefsirinde Müşkilü'l-Kur'ân (basılmamış yükssek lisans tezi), İstanbul, Marmara Ünv. Sosyal Bilimler Enstitüsü, 2003.

Sabri Demirci, Fahruddîn Râzî’nin Tefsiri Mefâtîhu'l-Gayb'da Müşkilü'l-Kur'ân: Kur'ân'da Çelişkili Âyetler Meselesi (basılmış doktora tezi), 2. bs., İstanbul, Nesil yay., 2005.

Muhammed Ali Ağılkaya, Kur'ân Müşkillerinin Giderilmesinde Tarihî Malzemenin Kullanımı (basılmamış yüksek lisans tezi), Ankara, Ankara Ünv. Sosyal Bilimler Ensitüsü, 2008.

Tuğba Nur Tuğut, Hak Dini Kur 'ân Dili Tefsirinde Müşkilü 'l-Kur'ân (basılmamış yüksek lisans tezi), İstanbul, Marmara Ünv. Sosyal Bilimler Enstitüsü, 2009.

Celil Kiraz, Şerif Murtazâ'nın Emâlî’ sinde Kur'ân Müskilleri ve Müteşâbihleri (doçentlik tezi), Bursa, Emin yay., 2010.

, “Şerif Murtaza'nın Kur’ân Müşkillerini Çözümlemede Kullandığı Yöntemler", Marife: Dini Araştırmalar Dergisi, C: X, sy. 3, s. 199-220.

Hasan Hüseyin Havuz, Çağdaş Müşkilü'l-Kur'ân (Muhammed Esed Örneği), (basılmış yüksek lisans tezi), Manisa, Boy Yayınları, 2015.

M. Halil Çiçek, Müskilü'l-Kur'ân'ı Yeniden Değerlendirmek, İstanbul, Beyan Yayınları, 2016.

Mehmet Akın, Nesefî Tefsirinde Müşkilü'l-Kur'ân (basılmamış doktora tezi), Ankara, Ankara Ünv. Sosyal Bilimler Enstitüsü, 2016.

Flamur Kasami, Kur'an'da Çelişkili Gibi Görünen Ayetler- İbn Kesir Tefsirinde Müşkilü'l-Kur'ân (basılmış yüksek lisans tezi), İstanbul, Rumuz Yayınevi, 2016.

Yedullah”, İslâmî Araştırmaları Dergisi, sy. 28 (1), 2017, s. 67-75.

Erkan Çakır, Mâturîdî'nin Te 'vîlât'inda Müşkilü'l-Kur'ân (basılmamış doktora tezi), Sakarya, Sakarya Ünv. Sosyal Bilimler Enstitüsü, 2017. 
Alican Dağdeviren-Erkan Çakır, "Mâturîdî’ye Göre Kurân-1 Kerim'de İşkâl Sebepleri”, Dinî Araştırmalar, C. XIX, sy., 50, 2016, s. 33-57.

Alican Dağdeviren-Erkan Çakır, "Mâturîdî’ye Göre İşkâlin Çözüm Yollarından Biri Olarak Cem" ve Tevfik", EKEV Akademi Dergisi-Sosyal Bilimler, sy., 70, Erzurum 2017, s. 21-37.

Necattin Hanay, "Cemâleddîn Aksarâyî'nin Müşkil Âyet ve Hadislere Dair Çözümlemesi”, I. Uluslararası Aksaray Sempozyumu (Tarih, Kültür, Din, Medeniyet), Aksaray 2016, s. 619-640.

Ahmet Karadağ, "Şîa Tefsirinde Müşkilü'l-Kur'ân: Muhammed Cevâd Muğniyye'nin et-Tefsîru'l-Kâş̧if Örneği”, Hikmet Yurdu Düşünce-Yorum Sosyal Bilimler Araştırma Dergisi, C: X, sy. 20, Malatya 2017, s. 167-196,

Eyüp Kaya, "Müşkil Âyetler Konusunda İbn Kuteybe-Elmalılı Hamdi Yazır Karşılaştırması”, Elmalılı M. Hamdi Yazır Sempozyumu Akdeniz Üniversitesi İlahiyat Fakültesi, Ankara 2015, s. 121-176.

Murat Bahar (Tanıtan), “Celil Kiraz, Şerif Murtazâ'nın Emâlîs'sinde Kur'ân Müşkilleri ve Müteşâbihleri, İstanbul, Emin Yayınları, 2010, 536 s.”, Usûl: İslam Araştırmaları Dergisi, sy., 27, Adapazarı 2017, s. 160-166.

Muhammed İsa Yüksek, "Müşkil Âyetler Bağlamında Zekeriya-Yahya Kıssası", Marife: Dini Araştırmaları Dergisi [Bilimsel Birikim], C: XV, sy. 1, Konya 2015, s. 67-86.

\section{Müsteşriklerin Kur'ân'da Tenâkuz Bulunduğu İddialarına Son Dönem- de Cevap Olarak Yazılan Bazı Eserler}

Rahmetullah el-Hindî (v. 1308/1891), İzhârü'l-hak, 4 c., nşr. M. Ahmed M. Abdülkâdir Halîl Melkâvî, Riyad, er-Riâsetü'l-âmme li-idârâti'l-buhûsi'l-'ilmiyye, 1414/1994.

Mohammad Khalifa, The Sublime Qur'an And Orientalism, New York 1983; 2. bs., Karaçi 1989.

Abdülcelîl Şelebî, Reddü müftereyâti'l-mübeşşirîn 'ale'l-İslâm, Riyad 1406/1985.

Abdülazîm İbrâhim Muhammed el-Mut'inî, Iftirââtü'l-müsteşrikîn 'ale'l-İslâm: Arz ve nakd, Kahire 1413/1992.

Abdurrahman Bedevî (v. 2002), Difâ'un 'âni'l-Kur'ân zıdda müntakıdîh (çev. Kemal Câdullah), ed-Dârü'l-'âlemiyye li'l-kütüb ve'n-neşr, ts.

Sâsî Sâlim el-Hâc, Nakdü'l-hitâbi'l-istişrâkî: ez-Zâhiretü'l-istişrâklyye ve eserühâ fí'd-dirâsâti'l-İslâmiyye, Beyrut 2002. 


\section{Sonuç}

Kur'ân ilimleri sahasının önemli nev'ilerinden birisi şüphesiz Müşkilü'l-Kur'ân disiplinidir. Müşkilü'l-Kur'ân ilmi, Kur'ân-1 Kerim'in anlaşılması ve muhafazasına önemli katkı sağlayan ilimlerdendir. Önceki dönemlerde bu ilim; kıraat ihtilafı, nazım bozukluğu iddiası, lahin, lafzın manasına muhalefeti, müşterek lafız, âyetler arasındaki zâhirî ihtilaf, müteşabih, mecaz, istiare, hazf, tekrar, ziyâde, kinâye, ta rîz ve benzeri konuları kapsarken Süyûtî ile birlikte bu ilmin tanımı hususi bir çerçeve kazanmış, sadece ilk bakışta aralarında teâruz izlenimi veren âyetleri konu etmeye başlamıştır. Nitekim mütekaddimîn döneminde birbiriyle içiçe ele alınan ilimlerin müteahhirîn döneminde müstakil olarak incelendiği malumdur. Süyûtî ile başlayan bu süreç de aynı fikrin bir ürünü olsa gerektir. Her ne kadar İbn Akîle tarafından Süyûtî’nin "müşkilü'l-Kur'ân" kavramına getirdiği tanıma eleştiriler olsa da Süyûtî'nin tanımı kabül görmüş olacak ki, kendisinden sonra onun belirlediği çerçevede çalışmalar süregelmiştir.

Bu ilme bihakkın vâkıf olmakla İslâm düşmanlarının Kur'ân'da tezat bulma çalışmalarına cevap verecek bir meleke kesb edilmiş olur. İslâm'a muhalif akımların Müslümanların zihinlerine şüphe düşürme maksatları bir nebze bertaraf edilmiş olur. Âyetler hakkında bilgisizlik ve yeterli düşünmeme neticesinde ortaya çıkan problemlere çözüm üretme kabiliyeti kazanılmış olur.

$\mathrm{Bu}$ çalışma vesilesiyle aralarında tenâkuz olduğu sanılan âyetler arasında hakikatte bir çelişki olmadığını bir kez daha görmüş olduk. Nitekim Kur'ân-1 Kerim, kendisinde çelişki olmadığını bizlere bizzat bildirmiştir (en-Nisâ 4/82). 23 sene içerisinde farklı zaman ve zeminlerde inmekle birlikte sanki bir defada inmişçesine âyetleri arasında ihtilaf bulunmaması bu Kitab'ın ilmiyle herşeyi kuşatan Cenâb-1 Hakk'ın kelamı olduğunun bir başka göstergesidir.

Konuyla ilgili yazılan eserlerde işkâli gidermek için çoğunlukla âyetlerin arasını birleştirme (te'lif) ve bunları yorumlama (tevîl), bazen de tahsis veya nesih yoluna gidildiğini görmekteyiz.

Araştırma esnasında gördük ki, gerek yurt içi gerek yurt dışındaki çalışmalar içerisinde verilen müşkilü'l-Kur'ân eserlerinin listesi tasnife tabi tutulmamıştır. I'‘âb, garîb kelimeler, fikıh ihtilafları ve müteârız gibi görünen âyetlere dair müşkillerin hepsi müşkilü’l-Kur'ân başlığında listelenmiştir. Oysa Müşkilü garîbi'l-Kur'ân ve Müsskilü i'râbi'l-Kur'ân gibi eserlerin ayrı kategoride sıralanmas1 araştırmacıya kolaylık sağlaması açısından önemlidir. Nitekim karma liste veren bu çalışmalar bu listeye uygun konuyu ele almamakta, i'râb müşkillerinden bahsetmemekle birlikte i'râb müşkillerine dair eserleri de müşkilü’l-Kur’ân eserleri 
arasında sıralamışlardır. Biz bu çalışmada sadece ihtilaflı zannedilen âyetlere dair yazılan ulaşabildiğimiz eserlerin listesini verdik.

Öneri mahiyetinde şunu da belirtmek istiyoruz. Âyetler arasındaki teâruz izlenimi veren durumları çözümleyen çalışmalar bulunmakla birlikte, lügat kaideleriyle, bilimsel hakikatlerle, duyularla ve akılla ilk bakışta çelişkili gibi görünen âyetleri ve hadisleri ele alan, günümüz problemlerine çözüm sunan müstakil çalışmaların yapılmasının faydalı olacağı kanaatindeyiz. Bu çalışmalar, müşkilü'l-Kur'ân ve muhtelifü'l-hadîs alanında günümüze kadar yapılan çalışmaları tamamlayıcı mahiyette olacaktır. Ayrıca âyetlerle hadîs-i şerifler arasında ihtilaf var olduğu sanılan konuların yeterince incelenip ortaya konulması da ilim dünyasına katkı sağlayacaktır. 


\section{Kaynakça}

Abdullah b. Hamed el-Mansûr, Müşkilü'l-Kur'âni'l-Kerîm, 2. bs., el-Memleketü'l-Arabiyyetü's-Su'ûdiyye, Dâr'ü-bni'l-Cevzî, 1433 h.

Abdülvehhâb Hallâf, ‘'Ilmü usûli’l-fikh, Kâhire, Dârü'l-hadîs, 1423/2003.

Ahmed b. Hanbel, er-Red 'ale’z-Zenâdıka ve'l-Cehmiyye fimâ şekket fỉhi min müteşâbih'il Kur'ân ve teevvelethü 'alâ gayri te'vîlih, nşr. Dagiş b. Şebîb el- 'Acmî, Kuveyt, Garas li’n-neşr ve't-tevzî‘, 1426/2005.

el-Âlûsî, Ebü's-Senâ Şihâbüddîn Mahmûd b. Abdillâh, Rûhu'l-me 'ânî fì tefsîri'l-Kur'âni'l- 'Azîm ve's-Seb 'i'l-Mesânî, 15 c., Beyrut, Dârü ihyâi't-türâsi'l-'Arabî, ts.

Bağdatlı İsmail Paşa, İzâü'l-meknûn fi'z-zeyl 'alâ Keşfi'z-zunûn 'an esâmi'l-kütüb ve'l-fünûn, nşr. Şerefeddin Yaltkaya-Kilisli Rifat Bilge, 2 c., İstanbul, Milli Eğitim Basımevi, 1945-47 (Beyrut, Dârü ihyâi’t-türâsi'l-'Arabî ofset, 1405/1985).

el-Buhârî, Ebû Abdillâh Muhammed b. İsmâîl, el-Câmi 'u's-sahîh, nşr. Mustafa Dîb el-Bugâ, 7 c., Beyrut, Dâr'ü-bni Kesîr, 1410/1990.

el-Cürcânî, Ebü'l-Hasen Muhammed b. Alî, et-Ta 'rîfât, Mısır, el-Matbaatü'l-hayriyye, $1306 \mathrm{~h}$.

Ebû 'Azbe, Hasan b. Abdülmuhsin, er-Ravzatü'l-behiyye fîmâ beyne'l-Eşấire ve'l-Mâtürîdiyye, Haydarâbâd, Meclisü dâireti'l-me‘ârif, 1322/1905.

Ebü'l-Beka el-Kefevi, Eyyub b. Mûsâ, el-Külliyyât: Mu'cem fi'l-mustalahât ve'l-furûki'l-lugaviyye, nşr. Adnan Dervîş-Muhammed Misrî, 2. bs., Beyrut, Müessesetü'r-risâle, 1419-1998.

Ebussuûd b. Muhyiddîn Muhammed, Irşâdü'l- 'akli’s-selîm ilâ mezâya'l-Kitâbi'lKerîm, nşr. Abdülvasîf Muhammed, 5 c., Kâhire, Darü'l-‘usûr, 1347 h. (Darü'l-fikr ofset, ts.).

Fîrûzâbâdî, Muhammed b. Yakub, el-Kâmûsü'l-muhît, Beyrut, Müessesetü'r-risâle, 1416/1996.

el-Haymî, Salâh, Fihrisü mahtûtâti dâri'l-kütübi'z-zâhiriyye: 'Ulûmü'l-Kurâni’l-Kerîm, Dimaşk, Matbûâtü mecmai'l-lügati'l-Arabiyye, 1403 h.

Hanay, Necattin, “Aksarâyî’nin Kitabü'l-Es'ile ve'l-Ecvibe’si ve Yorum Metodu", Dinbilimleri Akademik Araştırma Dergisi, c. XVII, sy. 2, 2017.

İbn Akîle, Cemâlüddîn Ebû Abdillah Muhammed b. Ahmed el-Mekkî, ez-Ziyâde ve 'l-ihsân fî 'ulûmi'l-Kur'ân, nşr. Muhammed Safâ Hakkî (nev' 1-45), Fehd b. Ali el-Ândes (nev' 46-90), İbrâhîm b. Muhammed el-Mahmûd (nev“ 91-119), Muslih b. Abdülkerîm es-Sâmidî (nev‘ 120-143), Hâlid Abdülkerîm 
el-Lâhim (nev‘ 144-154), 10 c., el-'İmârâtü'l-Arabiyyetü'l-müttahide, Merkezü'l-buhûs ve'd-dirâsât-Câmi'atü'ş-şârika, 1427/2006.

İbn Fâris, Ebü'l-Hüseyn Ahmed b. Fâris er-Râzî, Mu'cemü mekâyîsi'l-luga, nşr, Abdüsselâm Muhammed Harun, 6 c., Kâhire, 1366-1371/1946-1951, 13891392/1969-1972, (Bask1 yeri yok, Darü'l-fikr ofset, 1399/1979).

İbn Hacer, Ebü'l-Fazl Şihâbüddîn Ahmed b. Alî el-Askalânî, Fethü'l-Bârî bi-şerhi Sahîhi'l-Buhârî, 13 c., Kâhire, el-Matbaatü'l-hayriyye, 1319-1329 h.

İbn Kuteybe, Ebû Muhammed Abdullah b. Müslim ed-Dîneverî, Te'vîlü müşkili'l-Kur'ân, nşr. Sa'd b. Necdet Ömer, Beyrut, Müessesetü'r-risâle nâşirûn, 1435/2014.

İbn Reyyân, Șerefüddin, Hüseyin b. Süleyman, er-Ravzu'r-reyyân fì es 'ileti'lKur'ân, 2 c., nşr. Abdülhalim b. Muhammed Nassâr es-Selefî, el-Medinetü'l-münevvere, Mektebetü'l-‘ulûm ve'l-hikem, 1415/1994.

İbnü'l-Kıftî, Ebü'l-Hasen Cemâlüddîn Alî b. Yûsuf el-Kıftî, İnbâhu'r-ruvât 'alâ enbâhi' n-nuhât, 4 c., nşr. Muhammed Ebu'l-Fadl İbrahim, Kahire, Darü'l-fikri'l-Arabî, 1406/1986.

el-İskâfî, Ebû Abdillâh Muhammed b. Abdillâh el-Hatîb, Dürretü 't-Tenzîl ve gurretü't-te'vîl fí beyâni'l-âyâti'l-müteşâbihât fì Kitâbi'llâhi'l- 'âzîz, Beyrut, Dârü'l-kütübi'l-'ilmiyye, 1433/2012.

Kâdî Abdülcebbâr, Ebü'l-Hasen Abdülcebbâr b. Muhammed, Tenzîhü'l-Kur'ân 'ani'l-metâ 'in, nşr. Hidr Muhammed Nebhâ, Beyrut, Dârü'l-kütübi'l-'ilmiyye, 2008.

el-Konevî, Ebü'l-Fidâ İsmâil Vehbî b. Muhammed, Hâşiyetü'l-Konevî 'alâ Tefsîri'l-Beyzâvî, 7 c., İstanbul, el-Matbaatü'l-'âmire, 1286 h. (İstanbul, elMektebetü'l-Mahmûdiyye ofset, ts.).

el-Mecme'u'l-melikî li-buhûsi'l-hadâreti'l-İslâmîyye, el-Fihrisü'ş-şâmil li 't-türâsi'l-Arabiyyi'l-İslâmiyyi'l-mahtût: 'Ulûmü'l-Kur'ân, mahtûtâti t-tefsîr ve 'ulûmih, Amman, Müessesetü Âli'l-beyt, 1989.

Menna' el-Kattân, Mebâhis fì 'ulûmi'l-Kur'ân, 35 bs., Beyrut, Müessesetü’r-risâle, 1998/1418.

Muhammed Abduh b. Hasen Hayrillah, Müşkilâtü'l-Kur'âni'l-Kerîm ve tefsîrü sûreti'l-Fâtiha, nşr. M. Reşîd Rizâ, Kâhire 1323 h.; Beyrut, Dârü mektebeti'l-hayât, ts.

Muhammed Emîn b. Hayrullah el-Hatîb el-Ömerî, Tîcânü'l-beyân fî müşkilâti'l-Kur'ân, nşr. Hasan Muzaffer er-Rezzû, Bağdat, Matbaatü İşbîliyyeti'l-hadîse, 1404 h. 
Mukâtil b. Süleymân, Tefsîrü'l-hamsi mi'e âye mine'l-Kur'ân, nşr. Isaiah Goldfeld, Şefâ Amr [Filistin], 1980.

el-Mutayrî, Abdülmuhsin b. Zeben, De 'âva 't-tâinîn fi'l-Kur'âni'l-Kerîm fi'lkarni'r-râbi 'i 'aşsere'l-hicrî ve'r-red 'aleyhâ, Beyrut, Dârü'l-beşâiri'l-İslâmiyye, $1427 / 2006$.

en-Nedîm, Ebu'l-Ferec Muhammed b. Ebî Ya'kûb İshâk, el-Fihrist, nşr. Rızâ Teceddüd, Tahran, 1391/1971.

en-Nîsâbûrî, Ebu'l-Kâsım Mahmud b. Ebü'l-Hasen Ali, Vazahu'l-burhân fì müşkilâti'l-Kur'ân, nşr. Safvân Adnân Dâvûdî, 2 c., Dimaşk, Dârü'l-kalem, 1410/1990.

, Bâhirü'l-burhân fì müşkilâti me 'âni'l-Kur'ân, nşr. Suâd bint Sâlih b. Saîd Bâbekî, 2 c., Mekketü'l-mükerreme, Ümmü'l-kurâ Üniversitesi bs., 1419/ 1998.

er-Râgıb el-İsfahânî, Ebü'l-Kâsım Hüseyn b. Muhammed, el-Müfredât fî garîbi 'l-Kur 'ân, nşr. Safvân Adnân Dâvûdî, 4. bs., Dımaşk, Dârü'l-Kalem, 1430/ 2009.

es-Sâbûnî, Muhammed Ali, Safvetü 't-tefâsîr, 4. bs., 3 c., Beyrut, Dâr'ü-Kur'âni'l-Kerîm, 1402/1981.

es-San'ânî, Ebû Bekr Abdürrezzâk b. Hemmâm, Tefsîrü'l-Kur'ân, nşr. Mustafa Müslim Muhammed, 3 c., Riyad, Mektebetü’r-rüşd, 1410/1989.

es-Süyûtî Ebü'l-Fazl Celâlüddîn Abdurrahmân b. Ebî Bekr, el-İtkân fî 'ulûmi'l-Kur'ân, nşr. Mustafa Dîb el-Bugâ, 2 c., Beyrut, Dâr'ü-bni Kesîr, 1416/1996. $1408 / 1988$.

, et-Tahbîr fì 'ilmi't-tefsîr, Beyrut, Dârü'l-kütübi'l-'ilmiyye,

Subhî es-Sâlih, Mebâhis fì 'ulûmi'l-Kur'ân, 27. bs., Beyrut, Dârü'l-'ilm li'lmelâyîn, 2007.

Sülün, Murat, "Mahiyeti, Sebep ve Çözümleri Çerçevesinde Müşkilü'l-Kur'ân”, Kur'ân ve Tefsir Araştırmalart-III, İstanbul, 2002.

Şah Veliyyullah Ahmed b. Abdirrahîm ed-Dihlevî, el-Fevzü'l-kebîr fì usĥli 't-tefsîr (trc. Selmân el-Hüseynî en-Nedvî), Dımeşk, Dâru'l-gavsânî li'ddirâsâti'l-Kur'âniyye, 1429/2008.

Şeyhzâde, Muhammed b. Muslihiddin Mustafa el-Kocevî, Hâşiyetü Şeyhzôde 'alâ Tefsîri'l-Kâdı'l-Beyzâvî, 4 c., İstanbul, Hakîkat kitâbevi, 1415/1994. 
Tahâvî, Ebû Ca'fer Ahmed b. Muhammed, Şerhu mü̈skili' l-Âsâr, nşr. Şuayb elArnaût, 16 c., Beyrut, Müessesetü'r-risâle, 1415/1994.

et-Tehânevî, Muhammed b. Ali, Keşşâfü ıstılâhâti'l-fünûn ve'l- 'ulûm, Kalküta 1862 (İstanbul, Kahraman yayınları ofset, 1404/1984).

Yâkût el-Hamevî, Ebû Abdillah Şihâbüddîn Yâkût b. Abdillâh, Mu'cemü'l-büldân, 5 c., Beyrut, Dârü ihyâi't-türâsi'l-Arabî, 1399/1979.

Yerinde, Adem, “Müşkilü'l-Kur'ân”, DİA, C: XXXII, İstanbul, 2006.

ez-Zehebî, Ebû Abdillâh Şemsüddîn Muhammed b. Ahmed, Siyeru a 'lâmi'n-nübelâ, 25 c., Beyrut, Müessesetü'r-risâle, 1405/1985.

ez-Zerkeşî, Ebû Abdillâh Bedrüddîn Muhammed b. Bahâdır, el-Burhân fì 'ulumi'l-Kur'ân, nşr. Muhammed Ebü'l-Fazl İbrâhîm, 4 c., 3. bs., Kâhire, Mektebetü dâri't-türâs, 1404/1984.

ez-Ziriklî, Ebû Gays Muhammed Hayrüddîn b. Mahmûd, el-A'lâm Kamûsü terâcim li-eşheri'r-ricâl ve'n-nisâ min'el- 'arab ve'l-müsta 'rebîn ve'l-müsteşrikîn, 8 c., 15. bs., Beyrut, Dâru'l-'ilmi li'l-melâyîn, 2002. 